Article

\title{
The Behaviour of Siderite Rocks in an Experimental Imitation of Pyrometamorphic Processes in Coal-Waste Fires: Upper and Lower Silesian Case, Poland
}

\author{
Lukasz Kruszewski ${ }^{1}$ and Justyna Ciesielczuk ${ }^{2, *(1)}$ \\ 1 Institute of Geological Sciences, Polish Academy of Sciences (ING PAN), Twarda 51/55, \\ 00-818 Warszawa, Poland; lkruszewski@twarda.pan.pl \\ 2 Faculty of Natural Sciences, University of Silesia, Będzińska 60, 41-205 Sosnowiec, Poland \\ * Correspondence: justyna.ciesielczuk@us.edu.pl
}

Received: 18 May 2020; Accepted: 26 June 2020; Published: 29 June 2020

\begin{abstract}
Little is known of the influence of fluxes on the nature and the intensity of burning in coal-waste heaps. To gain some insight, two siderite samples, one each from coal-mining waste heaps in Upper- and Lower Silesian Coal Basins (Poland), were heated under identical conditions in a thermal chamber coupled to a powder X-ray diffractometer. Differences in the behaviour of siderite phase and the products of its decomposition, mainly magnetite, wüstite, and olivine, are discussed. The waste heaps sampled underwent self-heating and self-ignition catalysed by fluxes. Though the samples are unlikely to be truly representative of the Silesian basins, the heterogeneous behaviour they displayed on heating merits description and explanation, as siderite is an important widely known flux in pyrometamorphic processes.
\end{abstract}

Keywords: thermal chamber experiment; Powder X-ray Diffraction; pyrometamorphism; siderite; wüstite; magnetite; graphite

\section{Introduction}

In coal basins in Poland, siderite occurs mainly as concretions of different sizes and shapes within mudstones, coaly shales, sandstones, and conglomerates hosting coal seams. As is common worldwide, these seams can undergo spontaneous combustion influenced by numerous external and internal factors [1-6]. Combustion also occurs in coal-waste heaps that typically contain gangue in abundance [7-18]. In both situations, significant environmental problems can ensue. The combustion processes are almost unpredictable in their intensity, volume, and evolution.

Siderite is commonly used as a flux in ceramics industry. It might thus be suspected to play a similar role in the natural environment by potentially influencing the course of coal-waste burning. As the role of siderite in coal-waste fires is likely to be significant but not well known, some laboratory experiments with known substrate composition were conducted with the aim of delineating the sequence and the temperature ranges of mineral phases formed during heating under near-reducing conditions and to see what other phases formed when other minerals were present. Experiments were conducted on siderite samples (ca $10 \times 20 \times 40 \mathrm{~cm}$ ) collected from the Wełnowiec dump in the Upper Silesian Coal Basin (USCB, [19]) and the Nowa Ruda dump in the Lower Silesian Coal Basin (LSCB). The present work is a continuation of earlier thermal experiments conducted on a variety of coal-waste materials, in particular shales and shales intermixed with coal and siderite [19]. The goal was to thoroughly characterise and explain the different thermal behaviours of the LSCB siderite sample examined. The USCB sample was used for comparison. 


\section{Methods}

Powder X-ray diffraction (PXRD) coupled with an mri thermal chamber was used. This method, known as in situ high-temperature PXRD, is useful for imitating natural mineral-forming processes, as shown in our previous paper [19]. The diffractometer used was a Bruker AXS D8 ADVANCE model located in the X-Ray Diffraction Laboratory, Institute of Geological Sciences, Polish Academy of Sciences, Warsaw, Poland. It was equipped with a VÅNTEC-1 superfast linear position-sensitive detector (LPSD), a CoK $\alpha$ tube, and a $\mathrm{k} \beta$ filter. A monochromator was not present. A radiation-type thermal chamber was used for the experiments to address both phase compositions and thermal changes and the stability ranges of the particular compounds formed. Sample aliquots were introduced as ethanol suspensions and placed on a strip heater made of $\mathrm{Pt}_{90} \mathrm{Rh}_{10}$ with a laser-welded $\mathrm{Pt}-\mathrm{Rh}$ thermocouple (S-type). The strip heater was radiation-heated by a U-shaped element of the same composition. The chamber was pressurized using a BOC Edwards turbomolecular pump to protect the Kapton foil covering the chamber body. The experiments were run at $n \times 10^{-5}$ Torr, $n \sim 1$ (equivalent to $0.0013 \mathrm{~Pa}$ or $1.33 \times 10^{-8} \mathrm{bar}$ ). Samples were pre-heated to $30^{\circ} \mathrm{C}$ before starting the experiment and then heated from $100-1200{ }^{\circ} \mathrm{C}$ in $20^{\circ} \mathrm{C}$ intervals with a heating rate of $5^{\circ} \mathrm{C} / \mathrm{s}$. Each step $(60$ in total) was held for $15 \mathrm{~min}$ to ensure good crystallization conditions and to avoid glazing. During cooling, PXRD data were collected for each step, and the steps were divided by $100{ }^{\circ} \mathrm{C}$. PXRD scans $(0.02 \theta$ increment, $1 \mathrm{~s} / \mathrm{step}$ in the LPSD language equal to $416 \mathrm{~s}$ in the zero-dimensional detector language; this gives $\sim 44.4 \mathrm{~min}$ for each diffractogram collection) were run for each interval. After reaching $1200{ }^{\circ} \mathrm{C}$, the samples were slowly cooled to $30^{\circ} \mathrm{C}$ at a $1{ }^{\circ} \mathrm{C} / \mathrm{s}$ cooling rate. All the reflection attributions were done using iterative comparison with Powder Diffraction File PDF and Crystallography Open Database COD databases in EVA software (V.5.1, Bruker, Karlsruhe, Germany). For better readability, we refer to some heating products by their related mineral names while noting that they are only synthetic counterparts. Due to strong coincidence and low concentrations, some phase identifications must be treated with caution.

The in-situ high-temperature PXRD patterns allow the recording of all possible mineral phases that can form from the initial sample during heating up to $1200{ }^{\circ} \mathrm{C}$ but are not present in the final product. Their identification cannot be supported directly by any other method, as the sample remains in the chamber during the experiment. Phase identification could be supported in the future by other methods and experiments, e.g., analysis of quenched products from intermediate temperature steps, but the products would also contain the quenching stage.

However, minerals formed at all stages of the heating are known as products of natural fires caused by self-heating and self-ignition of coal-bearing rocks, whether in coal seams or in coal-waste heaps. Natural fires can differ in intensity and oxygen access depending on many factors but mainly on the composition of the burning material.

The chemical composition of the siderite phase was determined at the Inter-Institute Laboratory of the Microanalysis of Minerals and Synthetic Materials (Faculty of Geology, University of Warsaw, Warszawa, Poland) using a CAMECA SX-100 microprobe operated in wavelength-dispersive (WDS) mode at an accelerating voltage of $15 \mathrm{kV}$ with a beam current of $10 \mathrm{nA}$ and diameter of $3 \mu \mathrm{m}$. The following standards were used: diopside for $\mathrm{Si}, \mathrm{Ca}$, and $\mathrm{Mg}$, orthoclase for $\mathrm{Al}, \mathrm{Fe}_{2} \mathrm{O}_{3}$ for $\mathrm{Fe}$, rhodonite for Mn, Apat_BB for P, celestine for Sr, and barite for Ba.

\section{Materials}

The initial LSCB siderite sample contained possible traces of fluorapatite, pyrite, rhodochrosite ( $d=2.367,2.149$, and $\sim 1.982$, and shoulder-like $3.620 \AA$ reflections), and traces of quartz and kaolinite. Identification of ultra-trace interstratified species, possibly corrensite, a dachiardite-group mineral and dickite was uncertain. Quantitative phase analysis (QPA; Rietveld method; TOPAS v. 4.0 software; model statistics in \% are $R_{\mathrm{wp}} 3.39$, GOF $\left(\chi^{2}\right) 1.16$ and $D W 1.51$ where $R_{\mathrm{wp}}$ is the residual weighted-pattern, GOF is the goodness of fit, and $D W$ is the Durbin-Watson statistic) gives 79.1(9) siderite in wt.\%, 11.9(5) kaolinite, 4.6(7) rhodochrosite, 3.8(2) quartz, 0.44(43) fluorapatite, 
and 0.31(13) pyrite. Electron Probe Micro Analysis data of individual grains of siderite showed the wt.\% concentrations to be FeO (46.19-58.34; aver 49.6), MgO (1.46-6.32; aver 3.95), $\mathrm{CaO}$ (0.45-10.33; aver 6.30 with the richest $\mathrm{Ca}$-datapoint not attributable to ankerite), and $\mathrm{CO}_{2}(38.36-41.82$; aver 40.32 ; calculated by difference). Trace components included $\mathrm{P}_{2} \mathrm{O}_{5}$ (rarely $<$ detection limit $<0.41$ wt.\%; aver 0.27 ) with single records for $\mathrm{SiO}_{2}(0.09$ wt.\%), $\mathrm{CoO}(0.16)$, and $\mathrm{MnO}(0.23)$ with very minor Ti. The composition of the siderite, although variable, is always a Fe-dominant species and may be expressed as $\left.\left(\mathrm{Fe}_{0.78} \mathrm{Mg}_{0.11} \mathrm{Ca}_{0.11}\right)_{\Sigma 1.00}\left(\mathrm{CO}_{3}\right)_{1.02} ; n=13\right)$.

The USCB sample comprised, in wt.\%, 71.7(1) siderite, 13.8(1) illite, 6.8(1) pyrite, 4.4(8) quartz, 1.3(2) kaolinite, 1.3(1) chlorite-group species, and 0.70(20) dolomite. The related statistics are $R_{\mathrm{wp}}=10.44 \%$, GOF $=7.48 \%$ and $D W=0.06 \%$.

\section{Results and Discussion}

The two experiments were compared by juxtaposing diffraction patterns. The $100-400{ }^{\circ} \mathrm{C}$ stage comparison is shown in Figure 1 , the $500-800{ }^{\circ} \mathrm{C}$ stage in Figure 2, and the $800-1200{ }^{\circ} \mathrm{C}$ stage in Figure 3 (prograde metamorphism imitation). The final cooling products are compared in Figure 4. Detailed graphical depiction of the results for the cooling of the LSCB sample are shown in Figure 5 (1100-800 ${ }^{\circ} \mathrm{C}$ range) and in Figure $6\left(700-30{ }^{\circ} \mathrm{C}\right.$ range). Ascription of the $3.85 \AA$ reflection to the strip heater was unclear, and this reflection may have either been related to a substance absent in the databases used for iterative qualitative phase analysis or to another artifact.
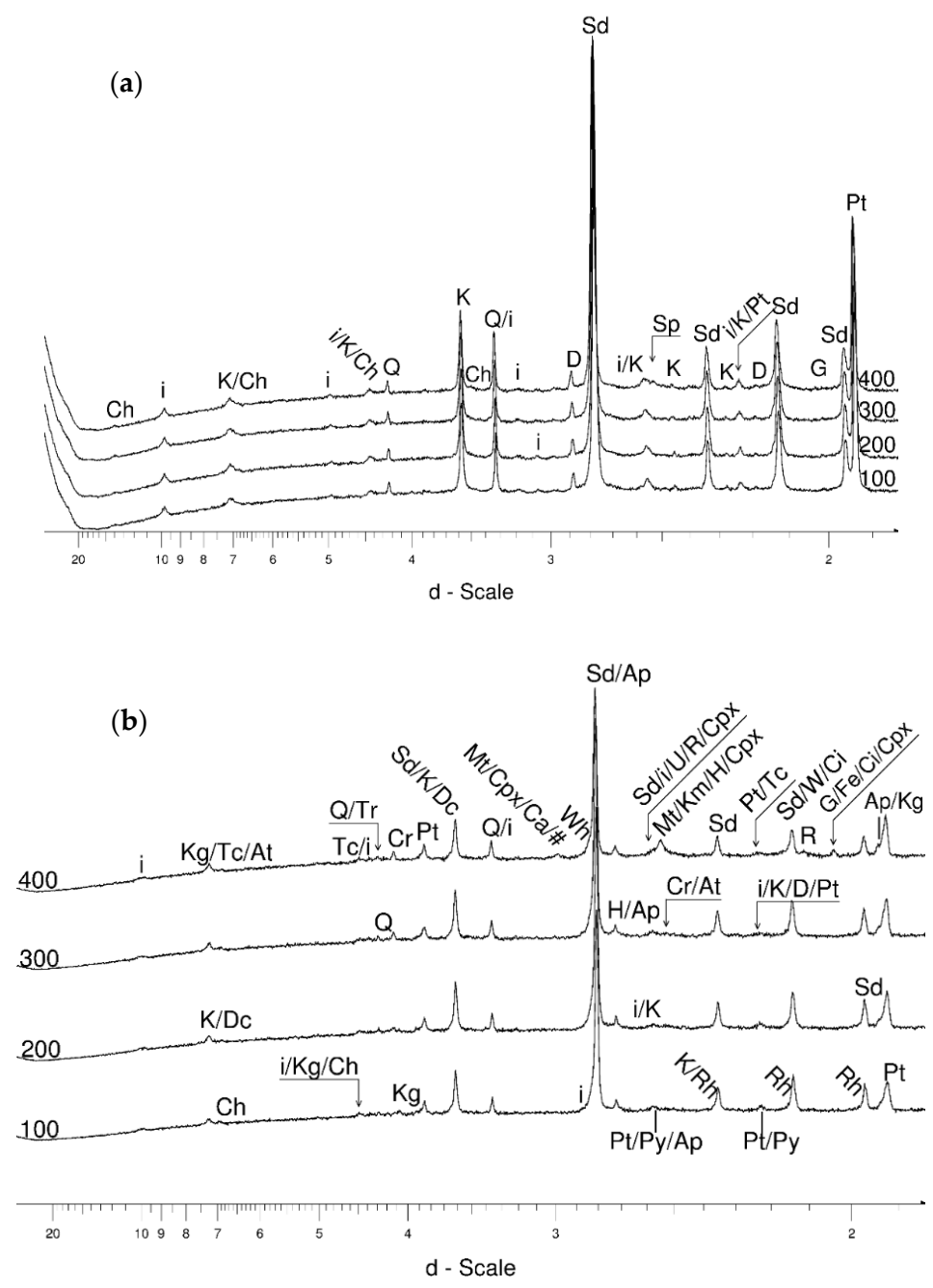

Figure 1. Results of heating $\left(100-400^{\circ} \mathrm{C}\right)$ two sideritic samples for comparison. 
(a) Upper Silesian Coal Basin (USCB) sample. (b) Lower Silesian Coal Basin (LSCB) sample. Ap-apatite group, At-antigorite, $\mathrm{Ca}-\mathrm{Ca}_{1.82} \mathrm{Al}_{3.64} \mathrm{Si}_{0.36} \mathrm{O}_{8}$ phase (see main text for details), $\mathrm{Ch}-$ chlorite group, $\mathrm{Ci}$-cohenite, $\mathrm{Cpx}$-clinopyroxene, $\mathrm{Cr}$-cristobalite (all polytypes), $\mathrm{D}$-dolomite, Dc-dickite, $\mathrm{Fe}$-metallic iron, G-graphite, $\mathrm{H}$-hematite, i-illite, $\mathrm{K}$-kaolinite, $\mathrm{Kg}$-kaolinite (sub)group, $\mathrm{Km}$-kamaishilite, Mt—magnetite, Q—quartz, Pt—PtRh strip heater (artefact), Py—pyrite, Sd—siderite, Sp—spinel phase, $\mathrm{R}$-rhönite-like phase, Rh—rhodochrosite, $\mathrm{Tc}$ - talc, $\mathrm{Tr}$ - tridymite (all polytypes), $\mathrm{U}$-ulvöspinel, $\mathrm{W}$-wüstite, $\mathrm{Wh}$-whitlockite, \#-C222 1 -structured $\mathrm{SiO}_{2}$. The $\mathrm{x}$ scale is in $\AA$, the $\mathrm{y}$ scale-number of counts is omitted.
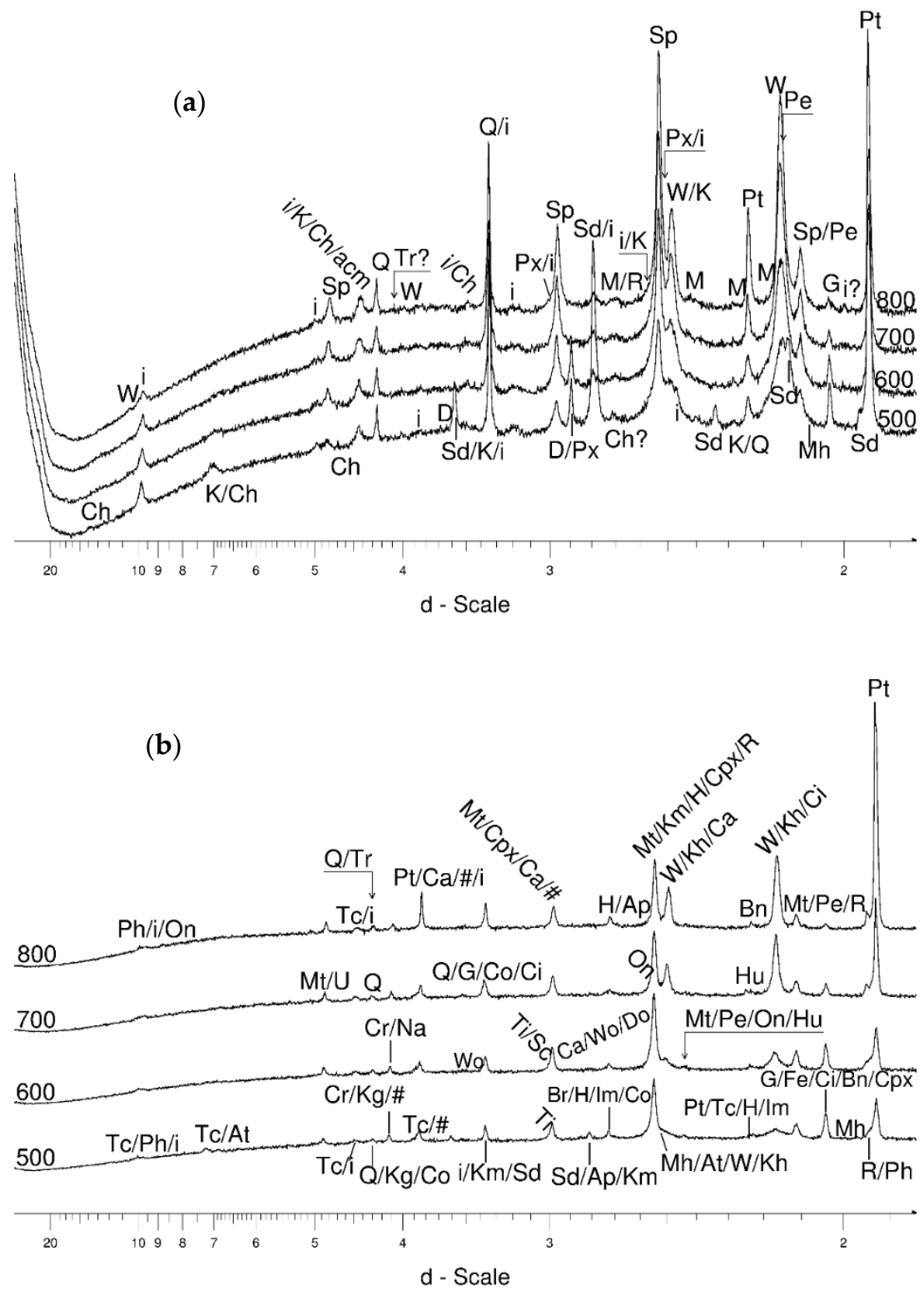

Figure 2. Results of heating $\left(500-800{ }^{\circ} \mathrm{C}\right)$ two sideritic samples for comparison. (a) USCB sample. (b) LSCB sample. acm-(semi)amorphous post-clay matter, Bn-barringerite, $\mathrm{Br}$-braunite, $\mathrm{Co}$-calcio-olivine, $\mathrm{Do}$-dorrite (or similar phase), $\mathrm{Hu}$-humite, $\mathrm{Px}$ - a pyroxene phase, $\mathrm{Kh}$-khamrabaevite, Im—ilmenite, $\mathrm{M}$ - mullite, $\mathrm{Mh}$ - maghemite, $\mathrm{Na}-\mathrm{NaAlSiO}_{4}$ phase, On-orientite, $\mathrm{Pe}-$ periclase, $\mathrm{Ph}$ - phlogopite or similar mica phase, Sc—scawtite, Ti-tilleyite, Wo-wollastonite. Other symbols and explanations as in Figure 1. 
(a)

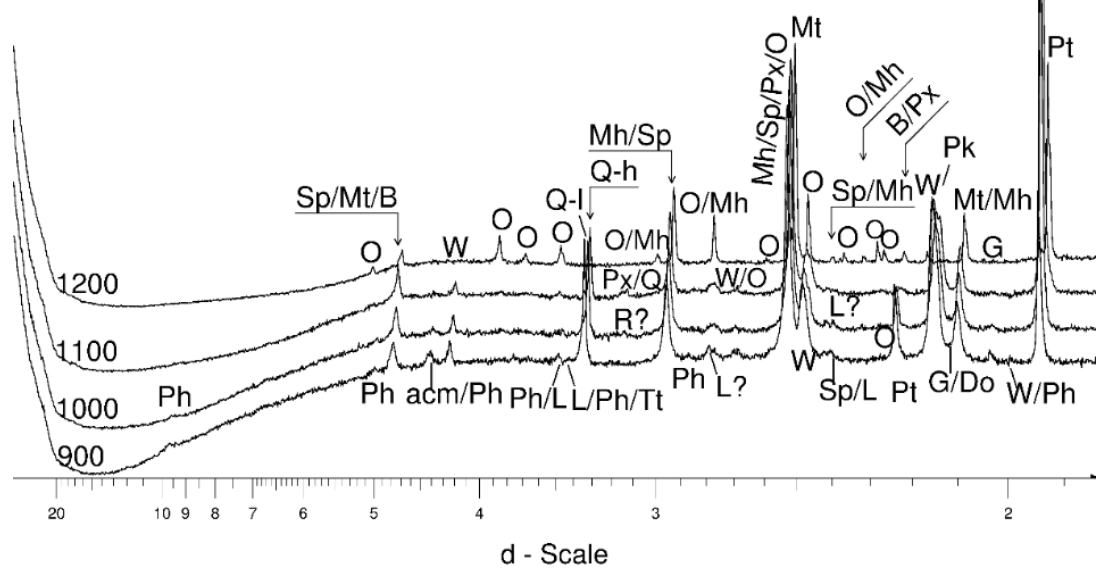

(b)

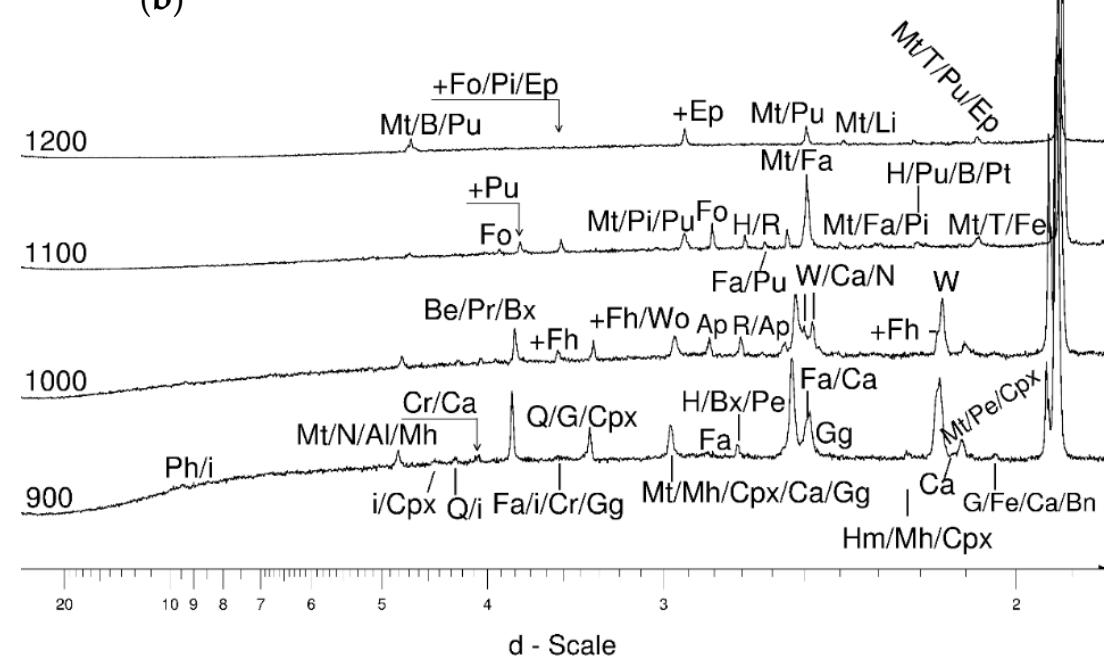

Figure 3. Results of heating $\left(800-1200{ }^{\circ} \mathrm{C}\right)$ two sideritic samples for comparison. (a) USCB sample. (b) LSCB sample. $\mathrm{Al}-\mathrm{C} 2 / m$-structured $\mathrm{Al}(\mathrm{OH})_{3}$ phase, $\mathrm{B}$-bayerite, Be-bernalite, $\mathrm{Bn}$-barringerite, $\mathrm{Bx}$ - bixbyite, Ep-epidote, $\mathrm{Fa}$-fayalite, $\mathrm{Fh}$-foshagite, $\mathrm{Fo}-$ forsterite, $\mathrm{Gg}$-greigite, $\mathrm{N}$-nordstrandite, L-laihunite, $\mathrm{Li}$-linzhiite, $\mathrm{O}-$ olivine group, $\mathrm{Pi}-$ piemontite-like phase, $\mathrm{Pk}$ - periclase, $\mathrm{Pu}-$ pumpellyite supergroup, $\mathrm{Q}$ - $\mathrm{h}$-high-temperature quartz, $\mathrm{Q}-\mathrm{l}-$ low-temperature quartz, T-troilite. Other symbols and explanations as in Figures 1 and 2. 


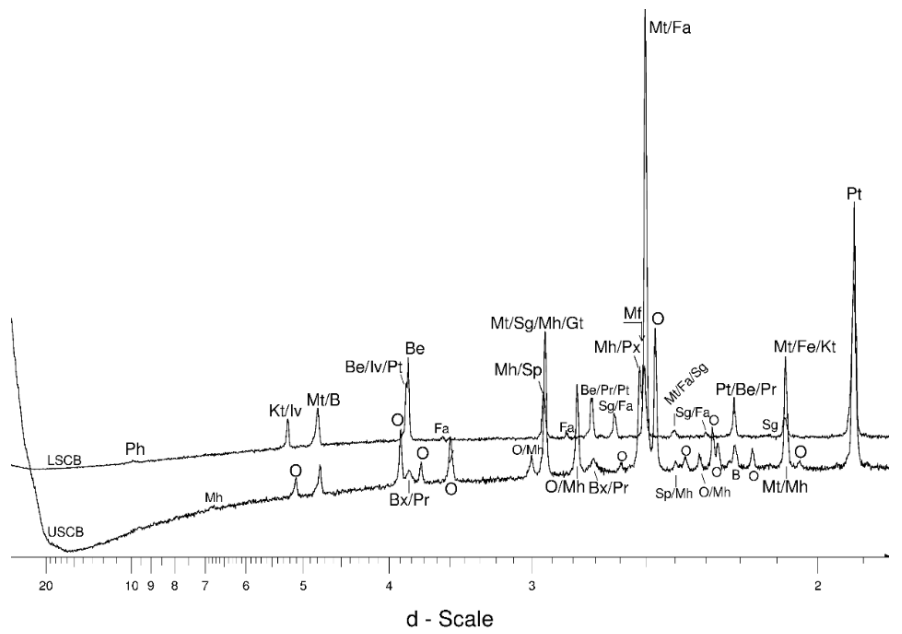

Figure 4. Final results of heating the two sideritic samples collected from the Upper- and the Lower Silesian Coal Basins. Gt—gibbsite, Iv—ilvaite, Kt—katoite?, Mf-magnesioferrite, Pr-perovskite, Sg-"skiagite". Other symbols and explanations as in Figures 1-3.

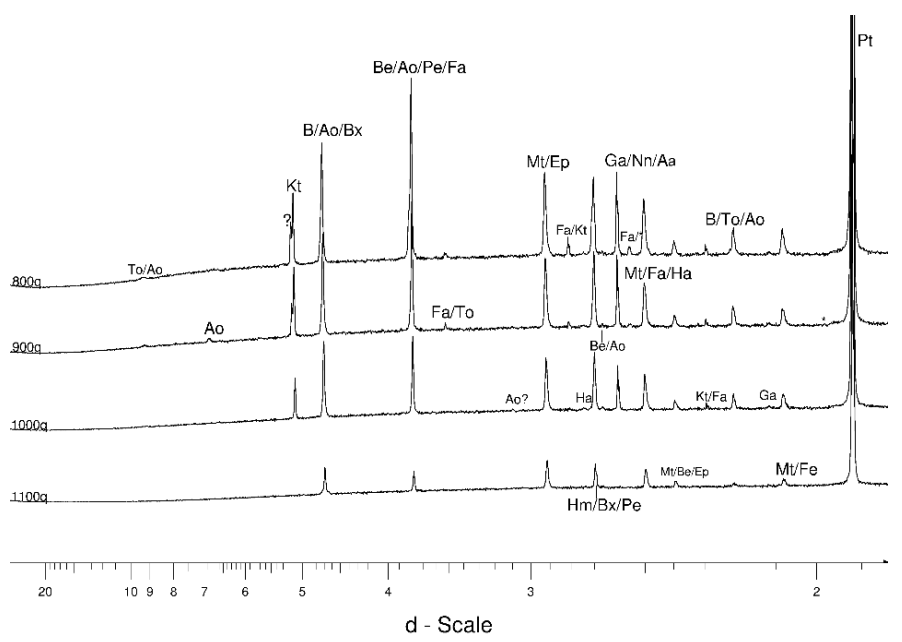

Figure 5. Results of cooling (q) of the LSCB sideritic sample over the $1100-800{ }^{\circ} \mathrm{C}$ range. Aa-alabandite, Ao-akatoreite, Ga-garnet supergroup, Ha-hausmannite, Nn-niningerite, $\mathrm{Pe}-$ perovskite, $\mathrm{To}-\mathrm{Ti}_{3} \mathrm{O}_{5}$ phase. Other symbols and explanations s in Figures 1-4.

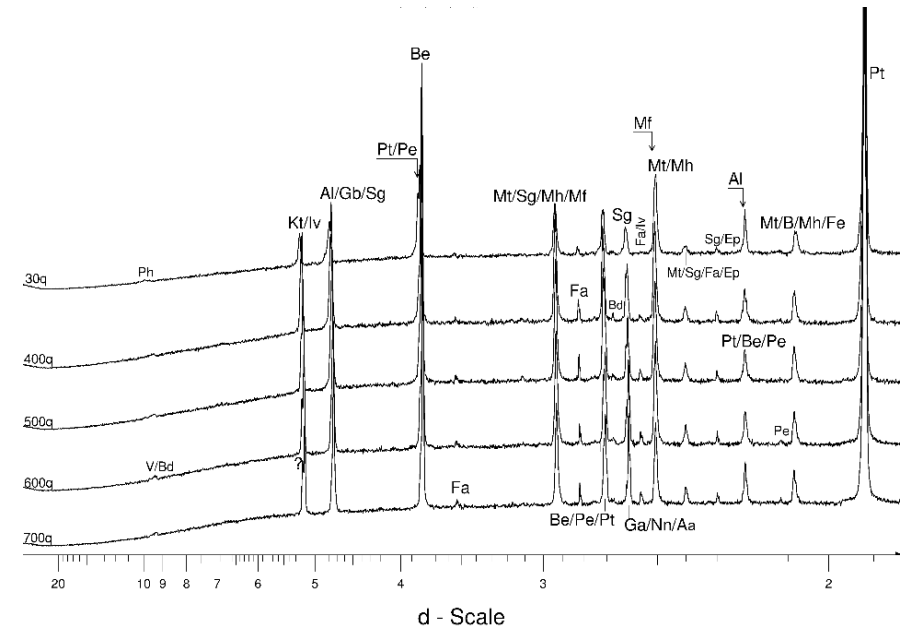

Figure 6. Results of cooling (q) of the LSCB sideritic sample over the $700-30{ }^{\circ} \mathrm{C}$ range. Bd-bredigite, $\mathrm{Gb}$ - gibbsite, $\mathrm{V}$ - vesuvianite. Other symbols and explanations as in Figures 1-5. 


\subsection{LSCB Siderite-Possible Phases Formed during the Heating-and Cooling Experiment}

The phase composition of the sample was intact at $100^{\circ} \mathrm{C}$. At $200^{\circ} \mathrm{C}$, a new reflection at $d=4.13 \AA$ appeared, attributable to cristobalite. Although its second intense reflection at $d=2.53 \AA$ was also present, the cristobalite identification was unconfirmed, as the latter coincided with kaolinite. It also coincided with $\mathrm{Pb}_{2} a$-structured $\mathrm{NaAlSiO}_{4}$ standard. Magnetite was already evident at $280{ }^{\circ} \mathrm{C}$ and possibly coexisted with a phase with a PXRD image that fit best to ulvöspinel $\left(\mathrm{TiFe}^{2+}{ }_{2} \mathrm{O}_{4}\right)$ at $400{ }^{\circ} \mathrm{C}$. The latter further blurred identification of the $\mathrm{NaAlSiO}_{4}$ phase due to coincidence, and the two also coincided with possible mica reflections. The chlorite-type reflection around $7 \AA$ was centred at $6.95 \AA$ at $300{ }^{\circ} \mathrm{C}$. As such, it may have possibly been ascribed, e.g., to cronstedtite $\left(\mathrm{Fe}^{2+}{ }_{2} \mathrm{Fe}^{3+}\left[(\mathrm{Si}, \mathrm{Fe})_{2} \mathrm{O}_{5}\right](\mathrm{OH})_{4}\right)$. Although traces of hematite were already possible at this step, any determination of such is questionable due to possible coincidence with evident pyrite and, to some extent, siderite.

At $\sim 390-400{ }^{\circ} \mathrm{C}$, a reflection attributable to either graphite or iron appeared at $d=2.04 \AA$. Traces of the supposed chlorite-like species were still possible at $400{ }^{\circ} \mathrm{C}$, with trace clinopyroxene arising as a new phase. Minor reflections at $2.85 \AA$ and $2.57 \AA$ may have been attributed to whitlockite $\left(\mathrm{Ca} 9 \mathrm{Mg}\left(\mathrm{PO}_{4}\right)_{6}\left(\mathrm{PO}_{3} \mathrm{OH}\right)\right)$. A $d=3.86 \AA$ reflection could have come from traces of $\mathrm{C} 222_{1}$-structured $\mathrm{SiO}_{2}$, but any such attribution was compromised by coincidence with an artefact related to the strip-heater. The supposed cristobalite polytype may have been associated with the Fd3m polytype. The 2.15 and the $2.155 \AA$ signals may have been attributed to wüstite $(\mathrm{FeO})$-a product commonly observed in both the USCB siderite heating experiments and others. The reflection then centred at $7.19 \AA$ may still have been attributed to cronstedtite or dickite-the higher-temperature counterpart of kaolinite that is stable up to ca $470{ }^{\circ} \mathrm{C}$ [20]. Kaolinite is supposed to be stable up to 350 or $400{ }^{\circ} \mathrm{C}[21,22]$. The 2.039 reflection was, again, ascribed to either graphite or iron. Another possibility was cohenite $\left(\mathrm{Fe}_{3} \mathrm{C}\right)$, possibly also responsible for the minor signal at $3.354 \AA$. Splitting of the $2.03 \AA$ reflection may have been suggestive of a mutual record of more than one mineral phase. The latter, however, may have been equally well related to a mica phase. The weak $2.726 \AA$ reflection best fit pyrite, less so hematite. More uncertain identifications at the $400{ }^{\circ} \mathrm{C}$ step were bustamite $\left(\mathrm{CaMnSi}_{2} \mathrm{O}_{6}\right)$ and rhönite $\left(\mathrm{Ca}_{4}\left[\mathrm{Mg}_{8} \mathrm{Fe}^{3+}{ }_{2} \mathrm{Ti}_{2}\right] \mathrm{O}_{4}\left[\mathrm{Si}_{6} \mathrm{Al}_{6} \mathrm{O}_{36}\right]\right)$.

Talc may be responsible for a faint fingerprint reflection present at $9.88 \AA$. However, nacrite $\left(\mathrm{Al}_{2} \mathrm{Si}_{2} \mathrm{O}_{5}(\mathrm{OH})_{4}\right)$ could not be excluded. The latter may have been responsible for a very weak reflection at $3.591 \AA$, which was also attributable to kamaishilite $\left(\mathrm{Ca}_{2}\left(\mathrm{Al}_{2} \mathrm{SiO}_{6}\right)(\mathrm{OH})_{2}\right.$, tetragonal, $a=8.85, c=$ 8.77) - a rare skarn mineral [23]. Such an exceptional identification may have been supported by the simultaneous detection of traces of wollastonite $\left(\mathrm{CaSiO}_{3}\right)$ and/or another Ca phase $\left(\mathrm{Ca}_{5} \mathrm{Al}_{10} \mathrm{SiO}_{22}\right.$; PDF00-024-0179, hexagonal, $a=5.0204, c=8.1673$, main reflections at $3.9596 \AA$ and $3.853 \AA$ ), hereafter referred to as $\mathrm{CAO}$. The latter phase could not be mistaken for forsterite, as other prominent olivine reflections were missing. It was likewise the case for pseudorutile (Ti source and a potentially related reflection at $2.754 \AA$ were missing). Titanium is usually found in the local coal-associating rocks in the form of rutile; its amount may have been too low for manifesting its reflection in the PXRD data. On the other hand, this may have simply been the case of a coincidence of Ti-rich ulvöspinel with a Ti-free spinel-phase standard. Fayalite was rather evident as a high-temperature $\left(900{ }^{\circ} \mathrm{C}\right)$ phase. Although the reflections of $\mathrm{CAO}$ coincided with the $C 222_{1}$-structured $\mathrm{SiO}_{2}$ phase, the related 3.861 reflection shifted towards higher angles with rising temperature. Additionally, a further reflection at $4.371 \AA$ suggestive of this silicate phase was lacking at the higher-temperature steps $\left(>500{ }^{\circ} \mathrm{C}\right)$. This observation seems to establish the existence of $\mathrm{CAO}$, and the $\mathrm{C} 222_{1}$-structured $\mathrm{SiO}_{2}$ phase could still occur in traces at $500{ }^{\circ} \mathrm{C}$. Precise identification of CAO was still hindered, as its major reflection at $2.9497 \AA$ may have somewhat coincided with an otherwise markedly shifted 2.9897 split reflection attributable to magnetite, clinopyroxene, and wollastonite.

At $420{ }^{\circ} \mathrm{C}$, an additional magnetite-related reflection at $4.89 \AA$ arose. The $2.147 \AA$ reflection was attributable to wüstite, graphite, and remnant siderite. The absence of high-angle reflections attributable to wüstite may have been due to a preferred orientation (100 direction) of its crystallites. Clinopyroxene was evident, and another reflection at $2.798 \AA$ fitting both kamaishilite and wüstite 
became apparent. While the $3.843 \AA$ signal was likely due to CAO, that at $3.215 \AA$ may possibly reflect phlogopite mica, as observed in one of our previous experiments [19]. The $3.00 \AA$ reflection was ascribable to both talc and esseneitic $\left(\mathrm{Fe}^{3+}\right.$-rich) clinopyroxene that are typical of pyrometamorphic rocks [19]). Although coinciding with hematite, braunite $\left(\mathrm{Mn}^{2+} \mathrm{Mn}^{3+}{ }_{6}\left(\mathrm{SiO}_{4}\right) \mathrm{O}_{8}\right)$ was likely confirmed by another reflection at $2.358 \AA$. Interestingly, reflections at $2.236 \AA$ and $2.048 \AA$ suggested the formation of barringerite, $(\mathrm{Fe}, \mathrm{Ni})_{2} \mathrm{P}$, at $420{ }^{\circ} \mathrm{C}$ as well. However, this phase became more obvious only between $500-600{ }^{\circ} \mathrm{C}$.

At $440{ }^{\circ} \mathrm{C}$, questionable traces of tridymite (with probable quartz coincidence at $d=4.32$ ) were noted. The reflection at $2.85 \AA$ was attributable to ternesite, $\mathrm{Ca}_{5}\left(\mathrm{SiO}_{4}\right)_{2}\left(\mathrm{SO}_{4}\right)$, which is known from some pyrometamorphic rocks (e.g., [24]). A very weak $2.977 \AA$ signal was suggestive of traces of wollastonite-2M. The main magnetite reflection at $2.997 \AA$ was split, likely due to clinopyroxene. At least some of the reflections close to those of magnetite ones were attributed to ulvöspinel with its intensity relative to the most intense sample reflection being $\mathrm{I}_{\mathrm{ulv}} / \mathrm{I}_{\max }=0.28$. Talc and at least one mica phase were confirmed by multiple reflections and their splits at ca10 $\AA(10.173,9.934$, and $9.970 \AA)$. An olivine solution phase was attributable to a diffuse $2.44 \AA$ signal, either lizardite- $1 T$ or phlogopite to another at $2.499 \AA$, a perovskite-supergroup species to yet another at $2.727 \AA$, and trace braunite and ilvaite to low-intensity signals between $2.723-2.712 \AA$. At $480{ }^{\circ} \mathrm{C}$, traces of larnite $\mathrm{Ca}_{2} \mathrm{SiO}_{4}$ (monoclinic polymorph), also known from natural pyrometamorphic rocks, e.g., [24], were possible, and any assignment of reflections at $2.71 \AA$ and $2.84 \AA$ to ilvaite was precarious due to the absence of splitting.

At $500{ }^{\circ} \mathrm{C}$, siderite was absent. A possibly related major reflection more likely derived from fluorapatite and/or kamaishilite. A very minor $1.969 \AA$ reflection that suggested that siderite was still present was more likely attributable to cronstedtite or nacrite. Wüstite-related signals are important at this temperature. The main reflection at $2.165 \AA$, and another reflection at $2.503 \AA$, may have been attributed to khamrabaevite, TiC. A weak reflection at $2.147 \AA$ may also have been attributed to wüstite; it fit another of its standards (PDF01-071-0161). This suggested that more than a single chemical variety of $\mathrm{FeO}$ was present. This is reminiscent of the well-known wüstite-periclase solid solution encountered in our previous experiments [19]. Periclase $(\mathrm{MgO})$ alone was difficult to confirm due to the coincidence of its $2.44 \AA$ reflection with magnetite. The $2.04 \AA$ reflection, ascribed to graphite, showed surplus intensity after standard fitting. In addition, the $3.39 \AA$ reflection of the supposed graphite was both very weak and likely coincided with the mica species. This may prove the occurrence of metallic iron. Cristobalite, in contrast, was rather evident, as shown by a clear signal at $2.53 \AA$. Trace of the aforementioned $C 222{ }_{1} \mathrm{SiO}_{2}$ was likely present. A prominent multiplicity of $2.11 \AA$ Aeflections may be described as coming from magnetite + clinopyroxene + rhönite-like species + periclase. A split of the $7.25 \AA$ signal was still likely due to talc. The reflections at $2.489,2.148,2.0397$, and $3.354 \AA$ A may still have corresponded to cohenite. Phlogopitic mica was rather evident at $d=10.091$. Coincidence with siderite and muscovite mica inhibited confirmation of kamaishilite survival. It was similarly so for fluorapatite. Another potentially admixed phase was maghemite, $\gamma-\mathrm{Fe}_{2} \mathrm{O}_{3}$-a typical component of a number of pyrometamorphic products (e.g., $[19,24])$-in its tetragonal $\left(P 4_{3} 2_{2}\right)$ form. This was the reason for relation of this signal to the strip heater.

Traces of olivines were still possible at $520^{\circ} \mathrm{C}$ but not $540{ }^{\circ} \mathrm{C}$, with possible trace ilmenite appearing. A non-intense reflection at $4.10 \AA$ on the $560^{\circ} \mathrm{C}$ graph may have been due either to tridymite or a muscovitic mica. Signatures at $2.543 \AA$ and $2.734 \AA$ may have been indicative of traces of ilmenite. Ulvöspinel may still have been present $(d=3.00 ; 4.91-4.92 \AA)$ alongside magnetite. New Ca silicates may have arisen at this stage, namely, tilleyite $\left(\mathrm{Ca}_{5}\left(\mathrm{Si}_{2} \mathrm{O}_{7}\right)\left(\mathrm{CO}_{3}\right)_{2} ; d=3.006 ; 2.973 \AA\right)$ and, less evidently, ultra-trace (i.e., below 2-3 wt.\%) scawtite $\left(\mathrm{Ca}_{7}\left(\mathrm{Si}_{3} \mathrm{O}_{9}\right)_{2}\left(\mathrm{CO}_{3}\right) \cdot 2 \mathrm{H}_{2} \mathrm{O}\right)$.

At $600{ }^{\circ} \mathrm{C}$, a clear amorphization of illite and/or a drop in the basal phlogopite reflection were noted. The best-fit polymorph at $660^{\circ} \mathrm{C}$ was the $3 T$ polymorph $\left(P 3_{1} 2_{1}\right)$. Reflections attributed to magnetite, and possibly ulvöspinel, were located at 2.44, 2.549, 2.547, and $2.540 \AA$. The intensity description of ulvöspinel was $\mathrm{I}_{\mathrm{ulv}} / \mathrm{I}_{\max }=0.27$. The $F d 3 m$ and the $P 2_{1} 3$ polytypes of cristobalite seemed to be still dominant among the silica species, with possible admixture of tridymite. Main reflections 
attributable to graphite were at 3.361 and/or $3.366 \AA$, with a possible additional one at $3.396 \AA$. The latter may also have come from wüstite. The intensity relations for graphite signals suggested that the $2.04 \AA$ reflection was mainly derived from metallic iron and cohenite. Reflections related to the mica phases ( $d=10.175$ and $9.939 \AA)$ were either weak or diffused. Traces of tridymite, a kaolinite/antigorite-like species, braunite, wollastonite, $\mathrm{CAO}$, scawtite, and ultra-traces of talc were possible. Actually, $600{ }^{\circ} \mathrm{C}$ is the upper stability limit of talc (e.g., [25]). Although antigorite (of PXRD pattern somewhat similar to that of talc) has a slightly higher stability of ca. $700{ }^{\circ} \mathrm{C}$, it was not expected here, as the latter stability concerns higher-pressure conditions (e.g., [26]). Clinopyroxene seemed to be a scarce species at this stage, as were calcio-olivine $(d=1.899)$ and cohenite. Reflections at $2.966 \AA$ and $2.237+2.049 \AA$ suggested trace amounts of magnesioferrite, $\mathrm{MgFe}_{2} \mathrm{O}_{4}$, and barringerite, respectively. The Na-rich species and $\mathrm{CAO}$ were undoubtedly absent at $640{ }^{\circ} \mathrm{C}$. The $\mathrm{C} 222_{1}$-structured $\mathrm{SiO}_{2}$ phase $(d=3.86$ and 4.12 or $4.116 \AA$ ), or possibly hexagonal tridymite, seemed to be dominant over cristobalitic phases, with tridymite- $M$ being accessory. At $680^{\circ} \mathrm{C}$, some of the magnetite-related reflections appeared to coincide with possible augitic pyroxene; this may have been responsible for the splitting of the $2.526 \AA$ signal. Ultra-trace tridymite- $M$, possible traces of periclase with additional trace phases-gibbsite $(d=4.842 \AA)$ and possibly srebrodolskite $\left(\mathrm{Ca}_{2} \mathrm{Fe}_{2} \mathrm{O}_{5}\right)$-may have been present. The mica phase was trace $(d=10.03)$, if present. Reflections $d=1.948$ and $d=2.486 \AA$ suggested the persistence of either perovskite or, more likely, calcio-olivine in the former case and CAO in the latter one. The coupled $3.856 \AA$ and very weak $3.824 \AA$ pair of reflections could be attributed to bernalite $\left(\mathrm{Fe}(\mathrm{OH})_{3}\right)$ at this stage, but its identification was blurred by extensive coincidence; it was more evident at further stages. Identification of bernalite should be treated with care due to its hydroxyl groups-a derivative of water. However, the pair did not exist at $800{ }^{\circ} \mathrm{C}$. In this instance, a migration of the $d=3.824 \AA$ bernalite reflection towards lower angles could not be ruled out.

At $700{ }^{\circ} \mathrm{C}$, mica phases were rather scarce. However, somewhat clearer reflections at $\sim 5.07 \AA$ and $2.40 \AA$ suggested muscovite. A clear rise of the intensity of the $4.09 \AA$ reflection was most likely related to the predominance of tridymite- $M$ among the silica species; this is supported by the enhanced signal at $3.817 \AA$ (alternatively, though less likely, attributable to bernalite). A minor signal at $3.399 \AA$ also suggested some high-temperature quartz. Clinopyroxene may also have been a larger part in the sample composition. Expansion of the $3.378 \AA$ reflection to a degree suggested a more extensive crystallization of graphite. On the other hand, the $3.378 \AA$ A reflection may also have been attributable to quartz. In addition, no such expansion was observed for the $2.04 \AA$ reflection. Thus, both iron and graphite rather seemed to diminish at the current stage $\left(700{ }^{\circ} \mathrm{C}\right)$, providing that the $\{0001\}$ preferred orientation was not an important factor. Trace calcio-olivine (but not larnite) and subordinate hexagonal tridymite, cristobalite, srebrodolskite, and CAO were still possible. Unconfirmed trace compounds included sarcopside $\left(\mathrm{Fe}^{2+}{ }_{3}\left(\mathrm{PO}_{4}\right)_{2}\right)$, bixbyite $\left(\mathrm{Mn}^{3+}{ }_{2} \mathrm{O}_{3}\right)$, mullite $\left(\mathrm{Al}_{4+2 x} \mathrm{Si}_{2-2 x} \mathrm{O}_{10-x}\right)$, and humite $\left.(\mathrm{Mg}, \mathrm{Fe})_{7}\left(\mathrm{SiO}_{4}\right)_{3}(\mathrm{~F}, \mathrm{OH})_{2}\right)$. Barringerite was still rather evident.

At $740^{\circ} \mathrm{C}$, illite was almost completely destroyed. Trace species included possible mullite, gibbsite, barringerite, $\mathrm{CAO}$, and tridymite- $M$. Trace wollastonite was still possible $(d=7.013)$. At this stage, wüstite was likely to be slightly more abundant than magnetite. Kaolinite, talc, and chlorites were certainly absent. From $700{ }^{\circ} \mathrm{C}$, hematite was not more evident than before, likely only becoming more abundant from $760^{\circ} \mathrm{C}$ upwards. However, the same may have applied to the coinciding bixbyite.

At $800{ }^{\circ} \mathrm{C}$, the CAO phase still appeared to be persistent, or even enriched, as at the $900{ }^{\circ} \mathrm{C}$ stage. The mica phase was also likely to be present; the reflections $d=4.28$ and $9.978 \AA$ fit to the 2 M1 polytype. The same was true for graphite; although the $2.04 \AA$ peak was almost completely diminished, those at $3.365 \AA$ and $2.13 \AA$ were evident. Uncertain and trace species included diopside, cristobalite, tridymite- $M$, hematite, ilmenite, maghemite, hausmannite $\left(\mathrm{Mn}_{3} \mathrm{O}_{4}\right)$, tilleyite, phlogopite, an orthopyroxene, and $\mathrm{Fe}_{3.6} \mathrm{Fe}_{0.9}\left(\mathrm{O}, \mathrm{OH}, \mathrm{SO}_{4}\right)_{9}$ phase.

At $840{ }^{\circ} \mathrm{C}$, both magnetite and qandilite-like spinels fit to the major reflections observed. Trace maghemite was still possible at $860^{\circ} \mathrm{C}$. At $900{ }^{\circ} \mathrm{C}$, fayalite seemed to be restored, coexisting with magnetite and wüstite. Clinopyroxene, low- and high-temperature quartz, and traces of cristobalite 
were possible, while muscovite seemed to be absent. A very low-intense reflection at $2.468 \AA$ may have been attributed to periclase.

Two possible wüstitic phases were present during the $900^{\circ} \mathrm{C}$ stage, with most prominent reflections at 2.154 and $2.483 \AA$ and at 2.163 and $2.495 \AA$, respectively. This separation may have been due to compositional differences related to the wüstite-periclase solid solution and, possibly, inclusion of $\mathrm{CaO}$ and $\mathrm{MnO}$ in it. Intermediate species were likely, as possibly evidenced by an additional reflection at $2.160 \AA$. The corresponding features at $1000{ }^{\circ} \mathrm{C}$ were 2.149 and $2.477 \AA$ and 2.160 and $2.500 \AA$, respectively. Graphite was likely at this stage.

At $1000^{\circ}$, the CAO phase was either absent or had its main reflection shifted to $3.806 \AA$. Another possibility was bernalite, with its second reflection again separated at $3.783 \AA$. This last observation suggested the current stage to be the most likely one related to the formation of $\mathrm{Fe}(\mathrm{OH})_{3}$. A reflection at $4.80 \AA$, although undoubtedly related to magnetite (or magnesioferrite), may also have been attributed to $\mathrm{Al}(\mathrm{OH})_{3}$ phase as nordstrandite, doyleite, or another monoclinic $(\mathrm{C} 2 / \mathrm{m})$ form. The $4.057 \AA$ reflection may have been related to both cristobalite and epidote. A feature at $2.565 \AA$ may have come from jacobsite $\left(\mathrm{MnFe}_{2} \mathrm{O}_{4}\right)$. Magnetite or magnesioferrite could be confirmed via the $2.529 \AA$ signal. Maghemite may have existed as both isometric $(2.511 \AA$ ) and tetragonal ( 2.514 and possibly $2.525 \AA$ ) phases. Another reflection from this range at $2.461 \AA$ could be associated with hercynite $\left(\mathrm{FeAl}_{2} \mathrm{O}_{4}\right)$. Wüstite (mainly $2.476 \AA$ ) , quartz, and fayalite $(2.818,3.531,2.544 \AA$ ) were confirmed, as was the evident wollastonite. Possible additional determinations concerned perovskite/bixbyite $(2.706 \pm 2.711 \AA)$ and fluorellestadite. The $2.704 \AA$ feature may have been attributed to hematite. Periclase was still present with $d=2.16 \AA$ potentially representing its dominant phase, with a possible additional phase related to $d=2.103 \AA$.

Wüstite was dominant at $1040{ }^{\circ} \mathrm{C}$ (with the best fit of PDF00-002-1180 standard, $a=4.296 \AA$ ), followed by "titanomaghemite" and magnetite. Perovskite admixture was not to be excluded. Another wüstite phase, or fayalite, may have been ascribed to a reflection at $d=2.498$ ( $a=$ $4.326 \AA$ ). The latter was also confirmed by other features at $2.833,3.523,3.533$, and $3.934 \AA$. The 2.700 and the $2.552 \AA$ signals suggested, to some degree, a rhönite-like phase. A complex $4.756 \AA$ reflection was attributable to a julgoldite-subgroup species of the pumpellyite group $\left(\mathrm{Ca}_{2}\left(\mathrm{Fe}^{2+}{ }_{,} \mathrm{Fe}^{3+}{ }_{,} \mathrm{Mg}\right) \mathrm{Fe}^{3+}{ }_{2}\left(\mathrm{Si}_{2} \mathrm{O}_{7}\right)\left(\mathrm{SiO}_{4}\right)(\mathrm{OH}, \mathrm{O})_{2} \cdot \mathrm{H}_{2} \mathrm{O}\right)$, though with a doubt due to its water content; pumpellyite sensu stricto was stable $<235{ }^{\circ} \mathrm{C}$ and the epidote + pumpellyite pair $<290{ }^{\circ} \mathrm{C}$ [27]. Clinopyroxene was a possible admixing phase $(d=2.942$ and 2.946). Quartz was ultra-trace. Wollastonite was difficult to confirm, which was also true for the CAO. Bernalite $(d=3.778 \AA)$ as well as nordstrandite and doyleite were still probable, as were söhngeite-type-structured $\mathrm{Fe}(\mathrm{OH})_{3}$ or $\mathrm{Al}(\mathrm{OH})_{3}$ species. A single phase of wüstite with its main reflection at $2.144 \AA$ was still present at $1080^{\circ} \mathrm{C}$.

At $1100{ }^{\circ} \mathrm{C}$, the $\mathrm{Al}(\mathrm{OH})_{3}$ compound(s) and bernalite were greatly diminished. Fayalite was more abundant, though not as much so as magnetite. However, it is important to note that the major $2.552 \AA$ reflection of fayalite may also have been attributed to a second phase of (titano)magnetite-type. Wüstite and nordstrandite were essentially absent. An important observation at this stage was the addition of forsteritic olivine to fayalite. Trace phases at this stage also included a rhönite-like phase and ye'elimite, $\mathrm{Ca}_{4} \mathrm{Al}_{6} \mathrm{O}_{12}\left(\mathrm{SO}_{4}\right)$.

It is noteworthy that, starting from $\sim 1200{ }^{\circ} \mathrm{C}$, the spinel phase best fit was to Si-substituted magnetite $\left.\left(\mathrm{Fe}_{0.32} \mathrm{Si}_{0.68}\right)\left(\mathrm{Fe}_{0.96} \mathrm{Si}_{0.04}\right)_{2} \mathrm{O}_{4} ; \mathrm{PDF} 01-089-6229\right)$. Most $\mathrm{Al}(\mathrm{OH})_{3}$ species were essentially absent. However, a prominent feature at $4.682 \AA$ may have fit to bayerite. Epidote was likely. The $2.077 \AA$ A reflection may still have been attributed to metallic iron but also to magnetite or hexagonal $\left(\mathrm{Pb}_{3} / \mathrm{mmc}\right)$ and possibly vacancy-free pyrrhotite.

During quenching, a division of the spinel-related signals was seen at $1000{ }^{\circ} \mathrm{C}$, the magnetite-ascribed reflection at $2.501 \AA$ and a possible hausmannite reflection at $2.488 \AA$. The latter was, however, absent in both the $1100{ }^{\circ} \mathrm{C}$ and the $900{ }^{\circ} \mathrm{C}$ patterns. At $1100{ }^{\circ} \mathrm{C}$, the partially cooled sample bore possible traces of epidote. Fayalite was a very minor species at this stage. A reflection at $2.117 \AA\left(1000{ }^{\circ} \mathrm{C}\right)$ possibly proved identification of an ardennite-like phase. 
Although neither As nor $\mathrm{V}$ were suspected to be enriched in the sample, an Si-dominant analogue, ardennite- $\left.(\mathrm{Si})\left(\mathrm{Mn}^{2+}, \mathrm{Ca}, \mathrm{Mg}\right)_{4}\left[\left(\mathrm{Al}, \mathrm{Fe}^{3+}\right)_{5} \mathrm{Mg}\right]\left(\mathrm{SiO}_{4}, \mathrm{AsO}_{4}\right)\left(\mathrm{SiO}_{4}\right)_{2}\left(\mathrm{Si}_{3} \mathrm{O}_{10}\right)(\mathrm{OH})_{6}\right)$, was suggested to exist in nature [28]. On the other hand, the latter species was suggested to be related to lavoisierite $\left(\mathrm{Mn}_{8}^{2+}\left[\mathrm{Al}_{10}\left(\mathrm{Mn}_{3}+\mathrm{Mg}\right)\right]\left[\mathrm{Si}_{11} \mathrm{P} \mathrm{O}_{44}(\mathrm{OH})_{12}\right)\right.$ - a P-rich analogue [29].

Bayerite was an evident and pronounced phase at $1000^{\circ} \mathrm{C}$, manifesting itself in the form of very intense reflections at $4.697 \AA$ and split $2.213+2.211 \AA$. Cooling the sample to $1000^{\circ} \mathrm{C}$ gave a product that seemed to fit garnet-structured katoite $\left(\mathrm{Ca}_{3} \mathrm{Al}_{2}(\mathrm{OH})_{12}\right)$, with $2.293 \AA$ being the major related feature, and to either an almandine- or a spessartine-like phase. The latter two were related mainly to a very pronounced signal at $2.608 \AA$ that clearly grew in intensity starting from $1000{ }^{\circ} \mathrm{C}$. The latter reflection may also have been attributed to "skiagite" $\left(\mathrm{Fe}^{2+}{ }_{3} \mathrm{Fe}^{3+}{ }_{2}\left(\mathrm{SiO}_{4}\right)_{3}\right)$, or eventually alabandite $(\mathrm{MnS})$ or niningerite $(\mathrm{MgS})$, in the diffractograms obtained for lower-temperature stages.

At $900-800{ }^{\circ} \mathrm{C}$, additional signals at $2.318,2.343$, and $1.981 \AA$ were noticed. These and a possible fingerprint reflection at $2.117 \AA$ were attributed to the ardennite-like phase. A phase likely to characterize the $900{ }^{\circ} \mathrm{C}$ stage was $\mathrm{Pa}$-3-structured silica based on reflections at 2.556, 2.216, 2.214, and $2.079 \AA$. Bayerite seemed to be a major and obvious compound at $800{ }^{\circ} \mathrm{C}$. A distinct phase attributable to "skiagite" may have been indicated by an additional $2.617 \AA$ reflection at $700{ }^{\circ} \mathrm{C}$. Trace bredigite, $\mathrm{Ca}_{7} \mathrm{Mg}\left(\mathrm{SiO}_{4}\right)_{4}$, was possible at the $900{ }^{\circ} \mathrm{C}$ stage and pyrosmalite- $(\mathrm{Fe}),(\mathrm{Fe}, \mathrm{Mn})_{8} \mathrm{Si}_{6} \mathrm{O}_{15}(\mathrm{OH}, \mathrm{Cl})_{10}$, at the $400{ }^{\circ} \mathrm{C}$ one.

The final, cooled product, bore the spinel phase-most likely magnetite. The major reflection at $3.831 \AA$ was likely attributable to bernalite with a strong preferred orientation; it somewhat coincided with perovskite. Any possible mismatch was due to temperature-driven changes of the related reflections. However, cell tuning made these reflections fit to the standard, with typical splits observed at $3.848+3.83$ and $2.719+2.713 \AA$. Admixtures of other Fe oxides such as maghemite (tetragonal) and magnesioferrite were possible. Katoite (followed by "skiagite") was initially identified as an essential component but was not found to be present in any of the Rietveld quantitative models. The best quantitative result obtained was as follows in wt.\%: 16.2(6) magnetite, 20.8(7) magnesioferrite, 19.8(3) bayerite, 10.5(9) fayalite, 8.0(2) ilvaite, 7.6(40 bernalite, 6.3(2) epidote, 4.8(1) maghemite (tetragonal), gibbsite 2.4(4), 2.1(1) skiagite, and 1.6(9) phlogopite (model statistics in \%: $R_{\mathrm{wp}}=6.85, \mathrm{GOF}=2.23, \mathrm{DW}$ $=0.46$ ). Thus, the reflection attributed to katoite may have been related to ilvaite. Epidote and wüstite may still have been present in trace amounts. Such observation was not necessarily true for periclase, iron, and graphite.

\subsection{Comparative Characterization with USCB Siderite}

A graphical representation of the heating of the USCB siderite was shown in our previous paper [19], but a detailed analysis of the process is delineated here in a comparative mode. The early $\left(100-400^{\circ} \mathrm{C}\right.$ ) heating stages were the most similar for both samples (Figure 1). In particular, a spinel phase arose at $\sim 400^{\circ} \mathrm{C}$ in both cases. A difference was apparent for graphite, which was already present at $100{ }^{\circ} \mathrm{C}$ in the USCB sample but at only ca $400{ }^{\circ} \mathrm{C}$ in the LSCB sample. However, this observation was somewhat blurred by the possible coexistence of metallic iron. Another major difference at the higher part of the early heating range was the more complex phase composition of the LSCB sample with talc/antigorite and possible hematite present. The major silica phase in the LSCB sample was cristobalite, already present at $300^{\circ} \mathrm{C}$. The tridymitic silica counterpart in the USCB sample was not observed, even at $400^{\circ} \mathrm{C}$.

Many more changes were observed over the medium-temperature stages (Figure 2). A chlorite-group phase was still present at $500{ }^{\circ} \mathrm{C}$ in the USCB sample. The disappearance of siderite occurred at $\angle 600{ }^{\circ} \mathrm{C}$ in the USCB sample-a process that occurred at a temperature about $100{ }^{\circ} \mathrm{C}$ lower in the LSCB sample. A somewhat complementary behaviour was found for graphite/iron; although its content increased up to the middle part of the $500-800^{\circ} \mathrm{C}$ stage, it began to cease from $500{ }^{\circ} \mathrm{C}$ in the USCB sample but only from $600^{\circ} \mathrm{C}$ in the LSCB sample. The USCB dolomite disappeared at a temperature slightly $>600^{\circ} \mathrm{C}$. The behaviour of the second carbonate phase-rhodochrosite-in 
the LSCB sample was difficult to define because of both low reflection intensity and coincidence. An important difference was the occurrence of a pronounced signal related to partially amorphized clayey matter in the USCB sample, even at $500^{\circ} \mathrm{C}$; this clayey matter was essentially absent (or unclear) at all temperatures in the LSCB sample. Periclase was more obvious (as a separate phase) in the USCB sample. A major difference between the two samples lied, again, in the phase composition; the much more complex LSCB sample contained phases completely absent in the USCB sample, namely, wollastonite (trace), humite, an additional silica phase, and, most importantly, barringerite. The growth of the spinel phase was much more pronounced at the medium-temperature stage in the USCB sample, as was the medium-temperature occurrence of traces of tridymite and the appearance of wüstite at a temperature slightly below $500^{\circ} \mathrm{C}$.

Differences between the two sideritic samples continued to grow at the highest-temperature stages. A major difference was the much more olivinic composition of the USCB sample. The LSCB sample was not only more saturated in the spinel phase but also exhibited a much more complex phase composition. The latter included Ca-rich and potentially Mn-bearing silicates, i.e., pumpellyite supergroup phase, epidote, a possible piemontite-like phase, foshagite, and fluorellestadite. It also included Ca-rich compounds, i.e., Ca aluminate and perovskite, possible reduced Fe compounds, i.e., pyrrhotite/troilite and linzhiite, and major hydroxides, i.e., bernalite and bayerite. It is also noteworthy that, although both samples contained olivines, that from the USCB seemed to have Mg and Fe fixed in a single, forsteritic phase, whereas, in the LSCB sample, the olivine was separated into fayalite and forsterite. This behaviour may have possibly been related to the significant dolomite component in the USCB sample. One of the few similarities between the samples was the possible development of a rhönite-like phase in both at similar temperatures. To some extent, they were also similar with regard to the occurrence of phlogopite, which existed up to $\sim 90{ }^{\circ} \mathrm{C}$ and up to $1000{ }^{\circ} \mathrm{C}$ in the LSCB and the USCB samples, respectively.

Wüstite seemed to be a major or dominant phase (as compared to magnetite) up to $\sim 600-700{ }^{\circ} \mathrm{C}$. The wustite count numbers grew up to a maximum at $600{ }^{\circ} \mathrm{C}$ (see below). From about this stage, magnetite was the major species formed. The final phase composition of the cooled USCB experiment product was, again, much simpler than that of its LSCB analogue. The best QPA model derived for it gave (in wt.\%): 51.6(2) forsterite, 42.5(1) magnetite, 2.1(1) hematite, 1.5(8) diopside, 1.2(1) phlogopite, $0.84(50)$ bayerite, and 0.25(32) maghemite (tetragonal). The corresponding statistical parameters, in percentages, are: $R_{\mathrm{wp}}=9.16, G O F=5.37, D W=0.08$. The LSCB sample heating product contained as much as two or three possible garnet-structured phases, with katoite and skiagite being the most evident. In their general magnetite-olivine rich composition and in the occurrence of traces of phlogopitic mica and perovskite/bixbyite, the two samples were notably similar. Ilvaite was another possible component distinguishing the LSCB sample, whereas the USCB sample had maghemite as a more evident (or separated) phase.

\subsection{The Behaviour of the Main Mineral Phases during the Experiment}

The physicochemical nature of our experiments was more reductive than oxidative, as confirmed by the formation of wüstite and, in particular, magnetite. However, some oxidation-related compounds also occurred, e.g., hematite and $\mathrm{Fe}^{3+}$-enriched diopside (this paper and [19]). It should be noted here that, although graphite identification was plausible, the related reflections were a somewhat better fit to iron.

In the LSCB sample, siderite was still clearly present at $400{ }^{\circ} \mathrm{C}$ but more or less completely absent at $500^{\circ} \mathrm{C}$. A fine crystalline-or "amorphous" form (or a precursor) of wüstite had already developed at $500{ }^{\circ} \mathrm{C}$. Its reflections got sharper and more prominent at $\sim 600^{\circ} \mathrm{C}$ as its content progressively grew during the heating process. Iron, assuming its correct identification, seemed to also arise at $500{ }^{\circ} \mathrm{C}$ with its content growing up to $600{ }^{\circ} \mathrm{C}$. From $620^{\circ} \mathrm{C}$, and especially $640^{\circ} \mathrm{C}$, its content diminished rapidly. Trace magnetite was already present at $400^{\circ} \mathrm{C}$, but its content dramatically rose from $500^{\circ} \mathrm{C}$-a growth that continued up to $\sim 640^{\circ} \mathrm{C}$. Thus, the behaviour of magnetite seemed to correlate with that of the 
(supposed) metallic iron and barringerite. As the magnetite and the iron behaviours were in inverse proportion to the growing content of iron, a simple reaction can explain it:

$$
\mathrm{Fe}_{3} \mathrm{O}_{4}+\mathrm{Fe} \rightarrow 4 \mathrm{FeO}
$$

Such a reaction is opposite to the well-known wüstite disproportionation reaction to magnetite and iron that occurs at $>250{ }^{\circ} \mathrm{C}$ in a reducing atmosphere (e.g., [30]). These authors, however, addressed the reduction of Fe oxides, including a three-stage process leading from hematite via magnetite and wüstite to metallic iron ( $\mathrm{T} \geq 570{ }^{\circ} \mathrm{C} ; \mathrm{CO}$ atmosphere). They also report pathways involving a $\mathrm{H}_{2}$ atmosphere, namely $\mathrm{FeO} \rightarrow \mathrm{Fe}_{3} \mathrm{O}_{4} \rightarrow \mathrm{Fe}\left(\mathrm{T} \geq 570{ }^{\circ} \mathrm{C}\right.$ ) or $\mathrm{FeO} \rightarrow \mathrm{Fe}_{3} \mathrm{O}_{4} \rightarrow \mathrm{FeO} \rightarrow \mathrm{Fe}$ (up to $880{ }^{\circ} \mathrm{C}$ ). The opposite observation in our case may have been related to differences in atmosphere composition and, possibly, heating rate.

\subsubsection{Siderite}

Siderite behaviour in terms of the relation of the full-width half-maximum of its major reflection (FWHM; calculated and reported in $2 \theta$ degrees; the instrumental resolution was $0.0652 \theta$ as derived from the $\mathrm{LaB}_{6}$ standard reflection localized nearest to the main 104 reflection of siderite), reflection position, and number of counts to temperature, was compared for the two samples and is juxtaposed in Figures 7-9.

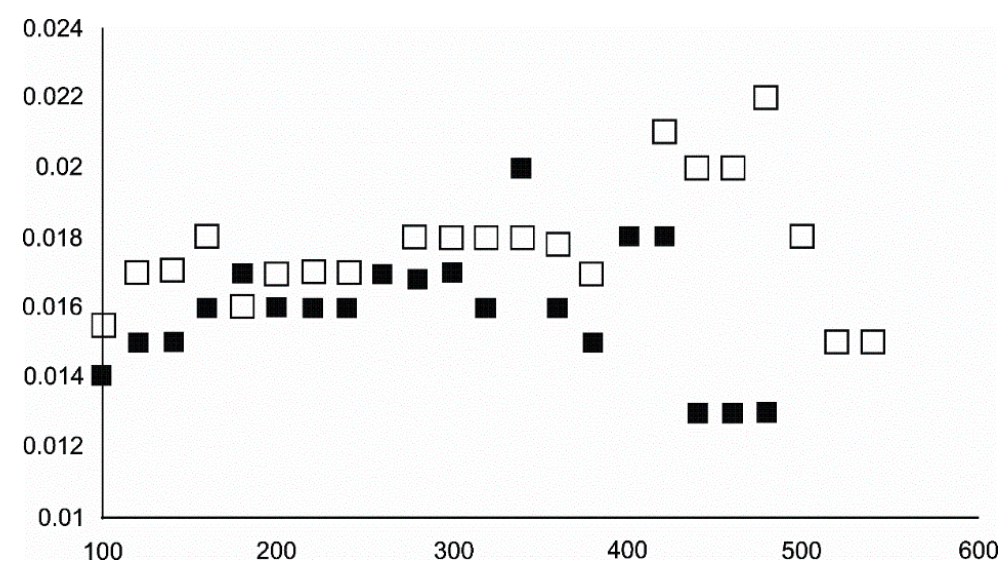

Figure 7. Relation of the full-width half-maximum (FWHM) parameter of siderite (in $2 \theta$ degrees, based on the 104 reflection) to temperature (bottom axis, ${ }^{\circ} \mathrm{C}$ ). LSCB—filled symbols. USCB—empty symbols.

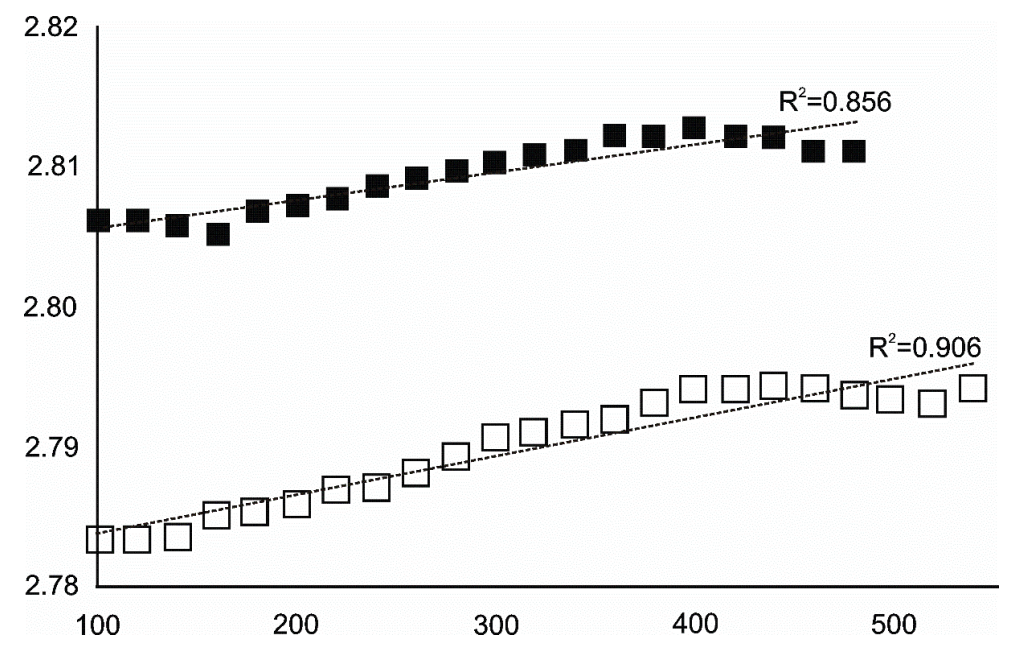

Figure 8. Relation of the main reflection $(\mathrm{hkl}=104)$ position (in $\AA$ ) of siderite to temperature (bottom axis, ${ }^{\circ} \mathrm{C}$ ). Symbols as in Figure 7. 


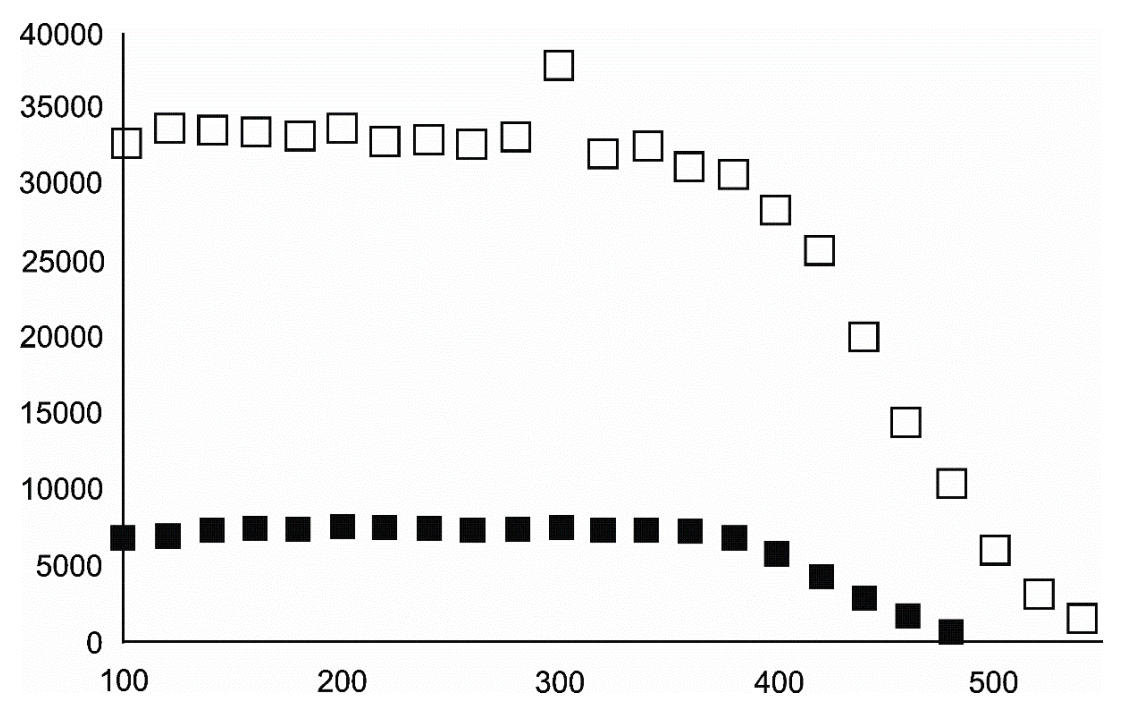

Figure 9. Relation of the number of counts (intensity) derived from the main reflection $(\mathrm{hkl}=104)$ of siderite to temperature (bottom axis, ${ }^{\circ} \mathrm{C}$ ). Symbols as in Figure 1.

The relationship of the FWHM parameter to temperature was non-linear, and variable trends were obtained for both samples (Figure 7). In general, the patterns of both were quite similar up to $420^{\circ} \mathrm{C}$. For the $420-480^{\circ} \mathrm{C}$ range, a slight rise in the parameter was observed in the USCB siderite from the USCB, a drop in the LSCB siderite. A similar pattern was obtained for both when comparing reflection position and temperature. The only difference in the path of the trends concerned the $100-160^{\circ} \mathrm{C}$ range; there, the trends were opposite. Although the trends were non-linear, markedly high $\mathrm{R}^{2}$ values characterized both. A rather large difference of the initial position (Figure 8) undoubtedly denoted a relatively large crystallochemical difference between the two siderites studied. The two graphs illustrating thermal dependence on the number of counts showed a good match (Figure 9). In particular, the parameter addressed began to drop from exactly $380^{\circ} \mathrm{C}$ in both, though the USCB siderite revealed a slightly more dynamic pattern.

\subsubsection{Magnetite and Wüstite}

The thermal behaviour of magnetite and wüstite was thoroughly investigated. The temperature relation to main-reflection FWHM, major reflection positions, and relative intensity in terms of number of counts is shown in Figures 10-15.

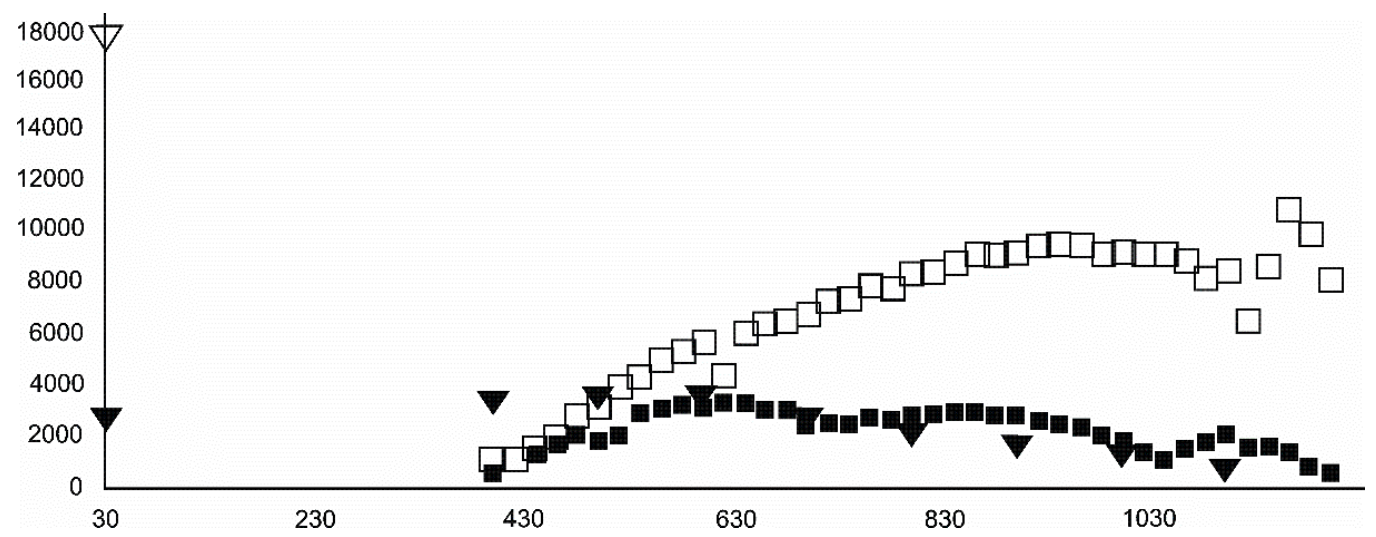

Figure 10. Number of counts (left axis, arbitrary units) versus temperature (bottom axis, ${ }^{\circ} \mathrm{C}$ ) for magnetite, as derived from the intensity of the main reflection $(\mathrm{hkl}=104)$. LSCB sample-filled symbols. USCB sample—empty symbols. Heating—squares. Cooling—triangles. 


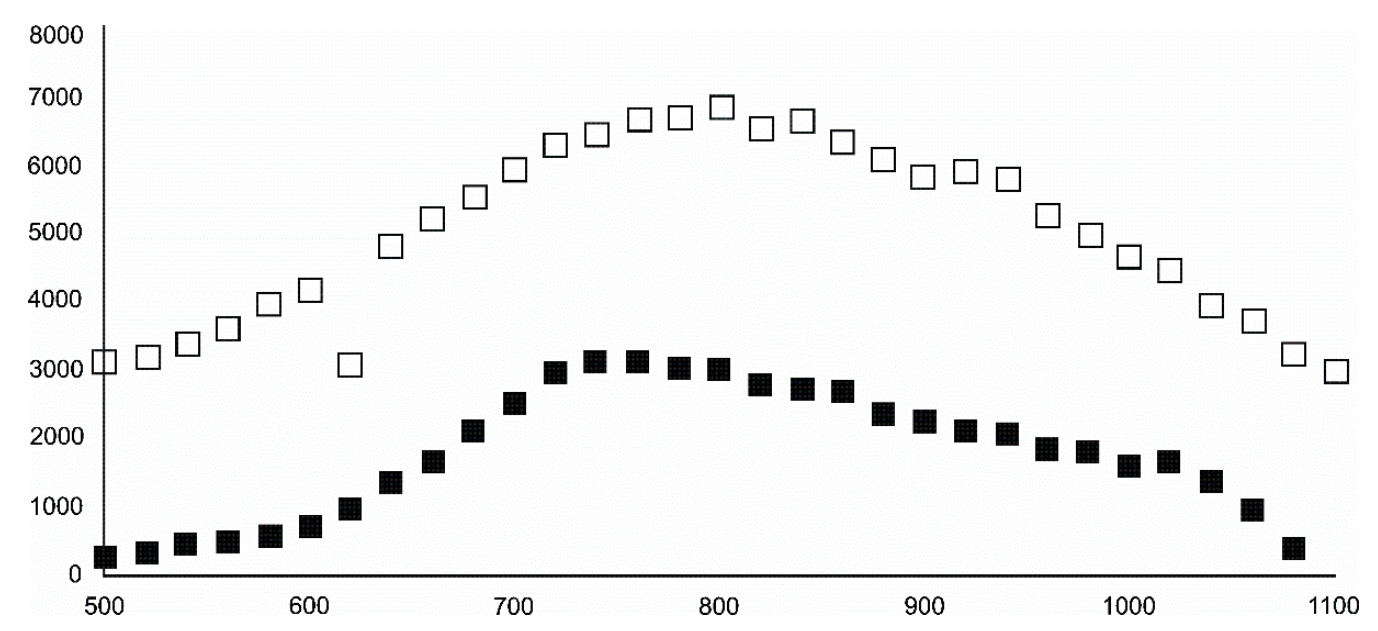

Figure 11. Progressive metamorphism imitation (heating) data for wüstite. Relation of temperature (bottom axis, ${ }^{\circ} \mathrm{C}$ ) to number of counts derived from the intensity of the main reflection (hkl = 200; left axis, arbitrary units). Symbols as in Figure 10.

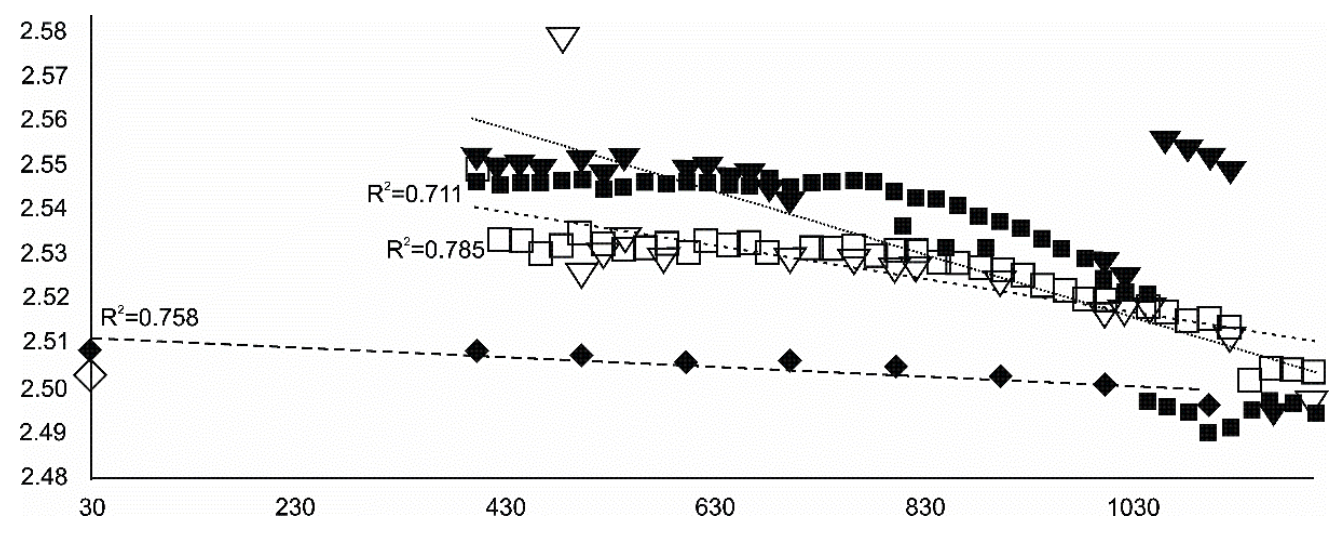

Figure 12. Relation of temperature (bottom axis, in ${ }^{\circ} \mathrm{C}$ ) to positions of major reflections (in $\AA$ ) for magnetite. LSCB sample—filled symbols. USCB sample—empty symbols. Squares-main reflection, heating. Triangles-major reflection second spinel-phase. Diamonds-main reflection, cooling.

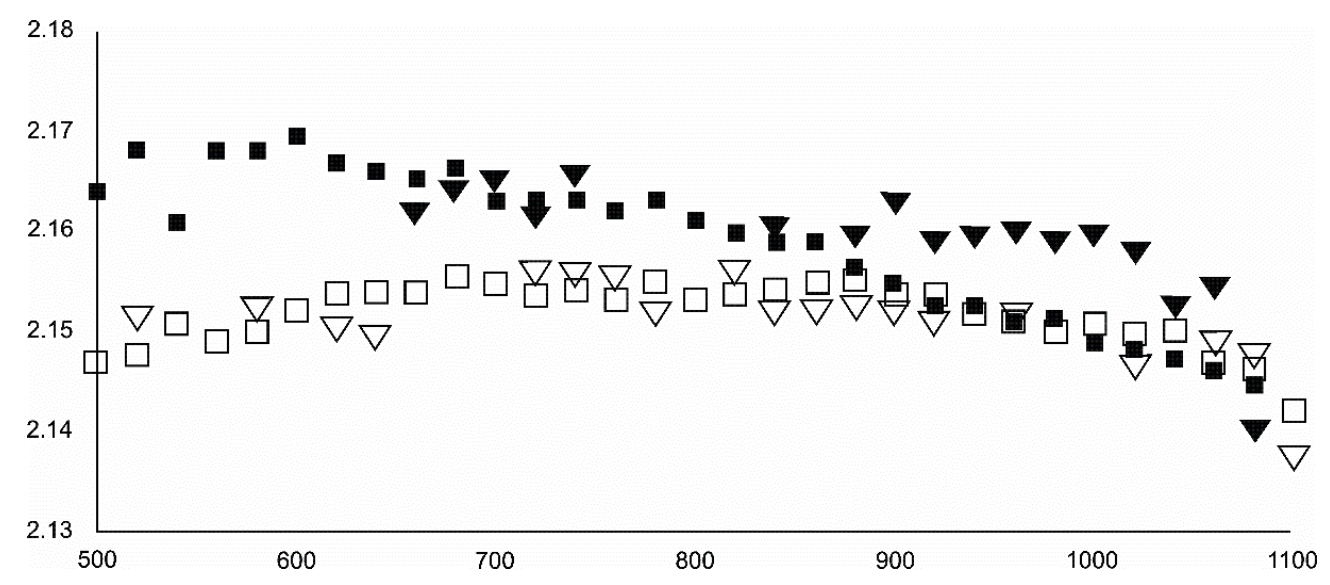

Figure 13. Relation of temperature (bottom axis, in ${ }^{\circ} \mathrm{C}$ ) to positions of major reflections (in $\AA$ ) for wüstite. LSCB sample-filled symbols. USCB sample-empty symbols. Squares-main reflection. Triangles-main reflection second-wüstite-phase. 


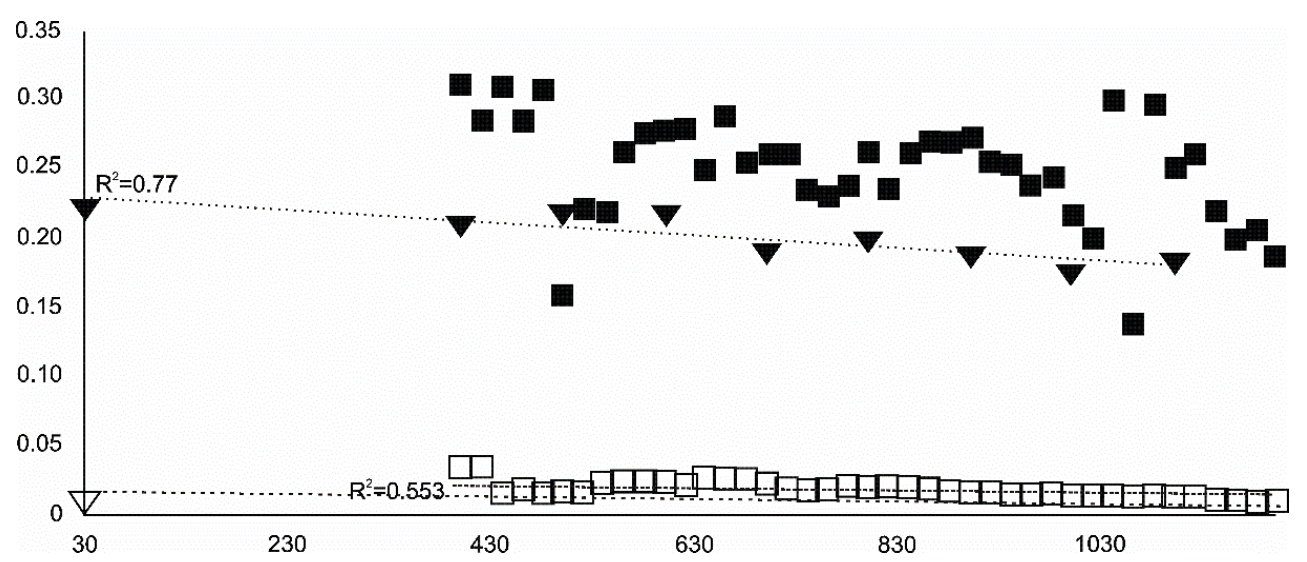

Figure 14. Relation of temperature (bottom axis, in ${ }^{\circ} \mathrm{C}$ ) to FWHM (left axis, as $2 \theta$ angular difference) for magnetite. LSCB sample-filled symbols. USCB sample-empty symbols. Squares-heating-related data. Triangles-cooling-related data. Data calculation was based on the main reflection.

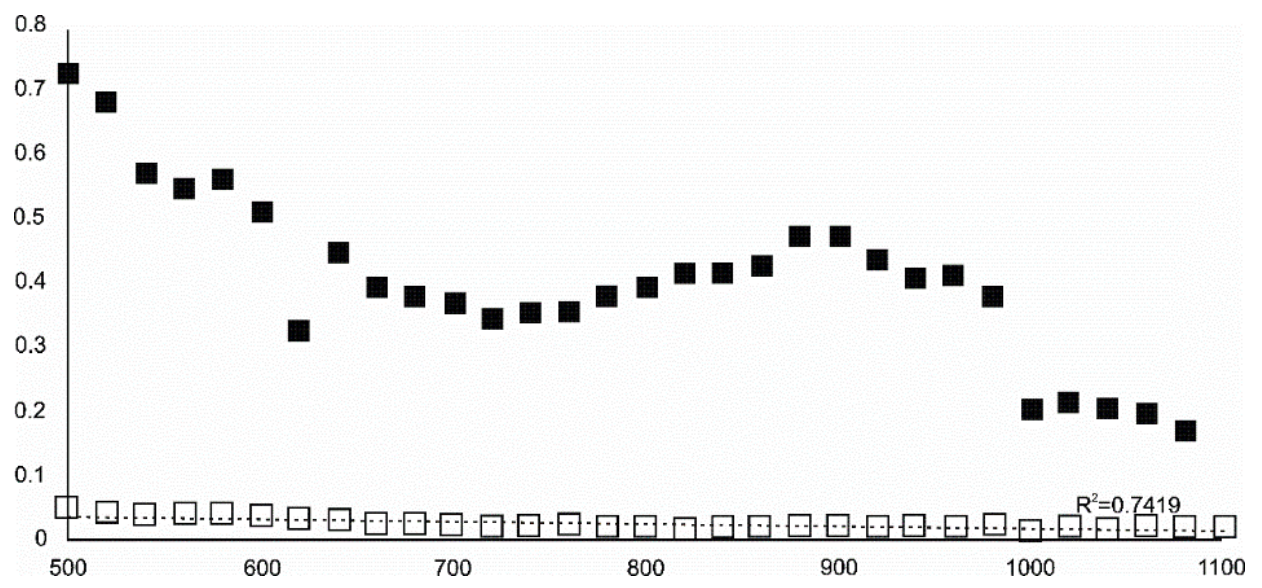

Figure 15. Relation of temperature (bottom axis, in ${ }^{\circ} \mathrm{C}$ ) to FWHM (left axis, as $2 \theta$ angular difference) for wüstite. LSCB data-filled symbols. USCB data-empty symbols. Data calculation was based on the most intense reflection.

No simple correlation of temperature to nucleation or to amounts of magnetite was evident (Figure 10). In the LSCB sample, magnetite seemed to show few saturation points at 480, 660-680 (maximum expected saturation), 860,1060 , and $1100^{\circ} \mathrm{C}$ during heating. The corresponding saturation in the USCB sample was in the $940-1040{ }^{\circ} \mathrm{C}$ range. However, complex behaviour indicating higher crystallization dynamics at high temperatures occurred at the $1100-1200{ }^{\circ} \mathrm{C}$ range; the content was variable and reached its maximum for the overall prograde part of the experiment at $1160{ }^{\circ} \mathrm{C}$. This observation suggested various generations of magnetite formation. During cooling, the greatest amounts of magnetite were expected $\sim 600^{\circ} \mathrm{C}$, being higher than those in the final heating product. In the LSCB sample, wüstite displayed a much simpler behaviour (Figure 11); saturation was reached at $780{ }^{\circ} \mathrm{C}$ with a minor second nucleation phase possible at $880^{\circ} \mathrm{C}$. The USCB wüstite had its peak content at $820{ }^{\circ} \mathrm{C}$. An extreme drop in its content occurred between $1120-1140{ }^{\circ} \mathrm{C}$, while only a very slight gain in the intensity was evident towards the highest temperature. However, in general, the course of the curve for both LSCB and USCB samples was similar, with clear nucleation stages at $700-800{ }^{\circ} \mathrm{C}$ and minor stages around $840-860$ and at $\sim 920^{\circ} \mathrm{C}$ (USCB) or $\sim 1020^{\circ} \mathrm{C}$ (LSCB). The position of the main magnetite reflection remained relatively stable up to $\sim 780-790{ }^{\circ} \mathrm{C}$ before dropping by $\sim 0.00262 \theta^{\circ}$ at $800{ }^{\circ} \mathrm{C}$. A much larger change occurred between $1020-1040{ }^{\circ} \mathrm{C}$, with the difference being $0.00432 \theta^{\circ}$ (LSCB); for the USCB sample, the trend was repeated, and the corresponding values shifted to $\sim 790-800{ }^{\circ} \mathrm{C}$ and $\sim 1130{ }^{\circ} \mathrm{C}$ (Figure 12). The shift was associated with the appearance of a third possible spinel phase and a clear splitting of the spinel-related reflections. Observations for 
the second spinel-related reflection were not direct, as they were blurred by coincidence with other species at various stages of the experiment. Nevertheless, the position of this second reflection seemed to be largely unchanged up to $<700{ }^{\circ} \mathrm{C}$-a point at which this reflection could not be easily located. The higher-temperature stages showed different position(s) of the second signal, with the differences largely due to the formation of new spinel varieties. Cooling was clearly responsible for the continuous, though small, shift in the position of the major magnetite reflection towards lower angles. The related correlation was high. An even higher negative correlation was found in the temperature-position relation for the major wüstite reflection; it progressively shifted towards higher angles in a more or less continuous manner (Figure 13). This was also evident for the second-phase wüstite, though the correlation was less clear. The FWHM parameter, related to crystallite size, showed large variations in the case of magnetite in both the LSCB and the USCB samples (Figure 14) with extremely low values related to the highest crystallinity at $500{ }^{\circ} \mathrm{C}$ and $1020^{\circ} \mathrm{C}$. Although we were unable to address the cause of this discrepancy between the two samples based on the data we had, we found fine (possibly micro-scale) processes related to large dynamics of the whole experiment as a possible factor. FWHM was related to crystallite size. It seemed likely that not thermal gradient (which was identical in the LSCB and the USCB cases) but differences in chemistry, e.g., of gaseous phase formed during the experiment, may have influenced it. As expected, the finest magnetite particles correlated with initial stages of its formation. Anomalies at $1040^{\circ} \mathrm{C}$ and $1080^{\circ} \mathrm{C}$ (LSCB) may have suggested some kind of dynamics of magnetite nucleation at higher temperatures, possibly related, as before, to the separation of new spinel varieties. In contrast to the prograde crystallization, retrograde magnetite formation seemed calmer; FWHM variations during cooling were minor. The temperature-FWMH relationship for the LSCB wüstite was much less complex (Figure 15). The FeO species clearly gained in crystallinity with the growing temperature, although the process did not seem to occur in a linear manner as for the USCB sample. One low extreme at $620^{\circ} \mathrm{C}$ possibly correlated with a large gain in the relative intensity of the major reflection while switching to the $640^{\circ} \mathrm{C}$ stage and a large FWHM drop between the 980 and the $1000^{\circ} \mathrm{C}$ stages suggested two major events of $\mathrm{FeO}$ crystallization.

\subsubsection{Olivine}

Gaining comparative data for the olivine phases proved difficult in both cases due to strong-and multiphase coincidence. Thus, the data below (Figures 16-18) are presented for thermal ranges for which the only evident olivine-related reflection was at $\sim 2.48-2.50 \AA$ (hkl = 112).

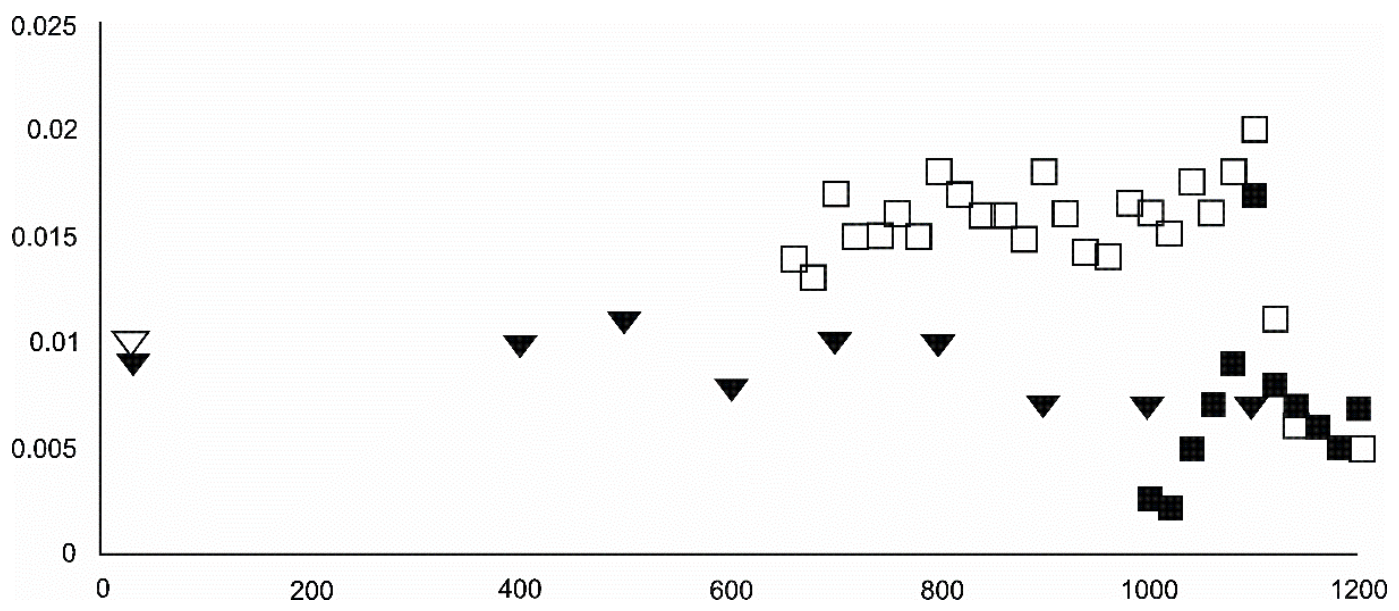

Figure 16. Relationship of temperature (bottom axis, in ${ }^{\circ} \mathrm{C}$ ) to FWHM (left axis, as $2 \theta$ angular difference) for olivine. LSCB data-filled symbols. USCB data-empty symbols. Squares-heating-related data. Triangles-cooling-related data. 


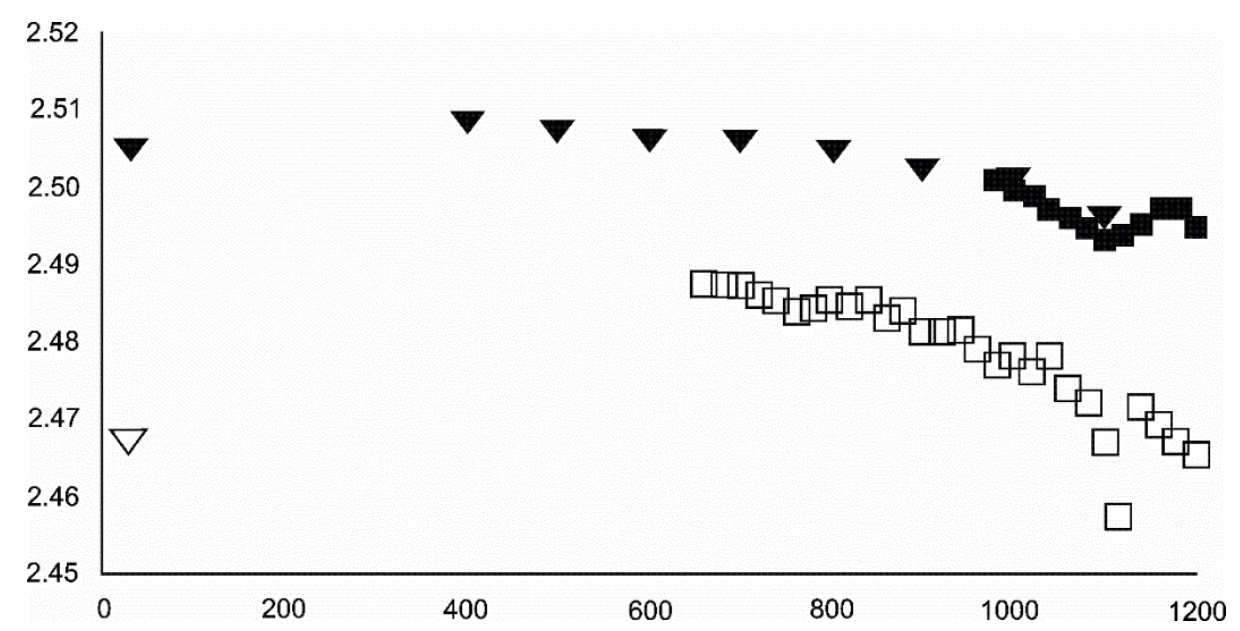

Figure 17. Relationship of temperature (bottom axis, in ${ }^{\circ} \mathrm{C}$ ) to position of the major reflection (in $\AA$ ) for olivine. Symbols as in Figure 1.

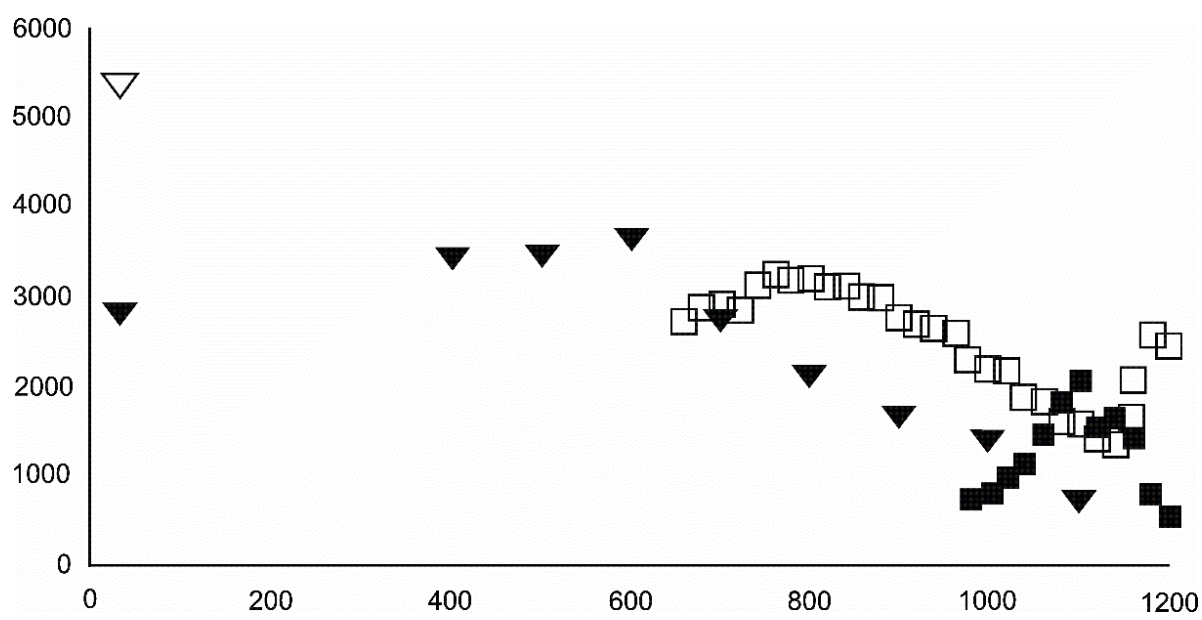

Figure 18. Relationship of temperature (bottom axis, in ${ }^{\circ} \mathrm{C}$ ) to number of counts (left axis, arbitrary units) for olivine. Symbols as in Figure 16.

The character of the pattern obtained for the FWHM parameter is similar for the two samples. In both, a linear growth up to $1100{ }^{\circ} \mathrm{C}$ is followed by a sudden fall (Figure 16). This confirms the high quality of the data. A slight rise in the FWHM parameter occurring between $1180-1200{ }^{\circ} \mathrm{C}$ for the LSCB sample is probably a transient phenomenon. The FWHM parameter derived from the cooling-related data of the LSCB sample shows a non-linear drop. Similar temperature-dependent behaviour characterizes the major reflection position (Figure 17). A general shift towards lower-angle positions during the prograde metamorphic experiment is observed for both samples. This change is of a two-phase character. However, the tangent temperature linking the two sub-stages is different for the two samples, being $1120^{\circ} \mathrm{C}$ and $1100^{\circ} \mathrm{C}$ for the USCB and LSCB samples, respectively. Also, the final sub-stages differ in function trajectory. An interesting dependence is evident in the prograde part of temperature-versus-counts diagram (Figure 18). The likely related nucleation process seems to be three-stage in the USCB sample and two-stage in the other. Probably the most striking difference concerns the thermal range that covers these changes. It is $660-720^{\circ} \mathrm{C}$ for the UCSB sample whereas, for the LSCB sample, it is clearly shifted towards higher-temperature of $980-1100{ }^{\circ} \mathrm{C}$. While former stages may be approximated inverse parabolas, the final sub-stages show opposed trajectories; nucleation continued during further heating of the USCB sample but ceased in the LSCB sample. Saturation is reached at $\sim 780-790^{\circ} \mathrm{C}$ in the USCB sample, at $\sim 1100{ }^{\circ} \mathrm{C}$ in the other. In both cases, olivines are 
more abundant in the retrograde part of the experiment although, in the final USCB product, their abundance is much greater.

\subsubsection{Other Phases}

Schreibersite is known to form in pyrometamorphic rocks related to coal fires in heaps (e.g., [31]). Some Fe phosphides and silicides most likely related to natural pyrometamorphism in one of the burning LSCB heaps have been noted [32]. These include a possible gupeiite $\left(\mathrm{Fe}_{3} \mathrm{Si}\right)$-schreibersite $\left((\mathrm{Fe}, \mathrm{Ni})_{3} \mathrm{P}\right)$ solid solution associated with native iron and also possible $\mathrm{Fe}_{7}(\mathrm{P}, \mathrm{Si})_{3}$ and $\mathrm{Fe}_{5}(\mathrm{P}, \mathrm{Si})_{3}$ species. Similar reductive phases are known to exist in the so-called "black blocks" [31]—soot-saturated, usually lenticular (rarely chimney-like) metapelitic bodies that are commonly observed in sections of USCB heaps. This includes the Czerwionka heap where murashkoite $(\mathrm{FeP})$, possible minor baringerite $\left((\mathrm{Fe}, \mathrm{Ni})_{2} \mathrm{P}\right)$, and very rare florenskyite (FeTiP) have been identified [33]. Schreibersite, barringerite and Fe-analog of melliniite were also identified at the heaps of Chelyabinsk coal basin [34]. Similar phosphides reside in the well-known Hatrurim Formation pyrometamorphic rocks in Israel (e.g. [35-37]), the parental rocks of which are sometimes termed the "meteoritic assemblage". A sarcopside-like oxidation product is also noted in the Czerwionka assemblages [34]. As further reflections related to metallic iron are outside the characterized PXRD range, its identification needs further confirmation. Florenskyite is titaniferous, as is the carbide species khamrabaevite preliminarily identified among the LSCB experiment products. However, we did not expect the existence of such Ti-rich species, or rhönite or aenigmatite, due to the lack of $\mathrm{Ti}$ in the protolith. Anatase $\left(\mathrm{TiO}_{2}\right)$ is a common constituent in many LSCB metapelitic rocks [38] but not in the sideritic rocks. On the other hand, reflections of magnetite are best attributable to Ti-bearing standards of this spinel phase. Additionally, the identification of ulvöspinel seemed to be possible, at least in terms of its reflections fitting to standards. These findings led to opposite conclusions regarding Ti enrichment of both the protolith and its daughter heating products.

Identification of phosphorus-bearing products, both phosphates and phosphides, in the LSCB heated sample suggested the presence of, e.g., fluorapatite in the protolith and minor enrichment of the original siderite in P. The USCB sample showed no evidence of such.

The identification of talc at low-temperature stages was plausible, as its decomposition is known to begin only at $500-650{ }^{\circ} \mathrm{C}$ (e.g., [39]). The same is true for epidote recently observed by Ł.K. in some archaeological, heat-treated objects. The possible identification of $\mathrm{Ca}$ aluminate species was reminiscent of well-known brownmillerite $\left(\mathrm{Ca}_{2}\left(\mathrm{Fe}^{3+}, \mathrm{Al}\right)_{2} \mathrm{O}_{5}\right)$ or mayenite-group occurrences in many pyrometamorphic rocks. The development of such species may also compare to the enrichment of some pyrometamorphic spinels in the $\mathrm{CaAl}_{2} \mathrm{O}_{4}$ component ("krotite equivalent"; e.g., [35,40]).

\section{Conclusions}

We show here that two relatively similar siderite-dominant samples behaved somewhat differently when subjected to identical thermal experiments. The differences observed were most likely related to differences in protolith mineralogy and in the crystallochemical character of the $\mathrm{FeCO}_{3}$ precursors. In particular, there was the occurrence of a trace apatite-group species (presumably fluorapatite $\left(\mathrm{Ca}_{5}\left(\mathrm{PO}_{4}\right)_{3} \mathrm{~F}\right)$ ), enrichment during heating of the LSCB siderite in $\mathrm{Ca}, \mathrm{P}$, and $\mathrm{Mg}$ leading to likely formation of Ca-rich minerals such as a CAO aluminosilicate phase, julgoldite/pumpellyite, and possibly trace epidote and barringerite as $\mathrm{Mg}$ moved mainly to olivine, wüstite-periclase, and possibly spinels. A trace admixture of rhodochrosite $\left(\mathrm{MnCO}_{3}\right)$ and occasional enrichment of Mn of the LSCB siderite explained the development on heating of the high-temperature Mn minerals braunite, bixbyite, and hausmannite. Mn substitution in the final spinel product remains to be confirmed.

The following are key observations arising from the heating experiment on the LSCB sample:

- $\quad$ Siderite was still present at $480{ }^{\circ} \mathrm{C}$ but diminished at $500{ }^{\circ} \mathrm{C}$ and, in the USCB sample, vanished at $\sim 560{ }^{\circ} \mathrm{C}$. 
- Magnetite crystallized from $400{ }^{\circ} \mathrm{C}$, with saturation expected at $660-680{ }^{\circ} \mathrm{C}$. Magnetite crystallization was dynamic during the progressive process, as evidenced from the FWHM-temperature relationship, although it was still an important phase at the higher-temperature end of the process. The retrograde crystallization of still abundant magnetite in the cooling sample was likely calmer with saturation being reached at $600{ }^{\circ} \mathrm{C}$-a temperature coinciding with that found for the progressive part of the experiment. Magnesioferrite admixture was especially possible in the $600-660^{\circ} \mathrm{C}$ range with positions of magnetite reflections at further stages seeming to suggest $\mathrm{Mg}$ substitution in the magnetite itself.

- Wüstite nucleation occurring in a semi-amorphous-like precursor at $500{ }^{\circ} \mathrm{C}$ was followed by a possible two-phase presence at $600{ }^{\circ} \mathrm{C}$. A major crystallization event was expected between $620-640{ }^{\circ} \mathrm{C}$. Saturation was reached at $780^{\circ} \mathrm{C}$ as well as a second possible major nucleation event at $\sim 880^{\circ} \mathrm{C}$. Traces of wüstite were expected to be present between $1080-1100^{\circ} \mathrm{C}$.

- Olivine became an important admixing species from $\sim 900^{\circ} \mathrm{C}$ or, more definitively, $\sim 1100{ }^{\circ} \mathrm{C}$. Saturation in the prograde part was reached at two steps in the USCB sample $(\sim 780-790$ and $\sim 1180^{\circ} \mathrm{C}$ ) and at $\sim 1100^{\circ} \mathrm{C}$ in the LSCB sample. Low- and mid-temperature counts-to-temperature function trajectories were similar but shifted towards higher temperatures in the LSCB siderite.

- Metallic iron and the garnet-structured skiagite were unconfirmed but possible additional final heating products. Iron seemed to grow up to $600{ }^{\circ} \mathrm{C}$ and then began to disappear. Its observed reflection seemed to change little in terms of its barycentrism throughout the entire process, suggesting a lack of diadochy substitutions.

- Barringerite constituted an important reduced Fe phase formed during the experiment.

- Cohenite was possible, especially in the $600-700{ }^{\circ} \mathrm{C}$ range. At $800{ }^{\circ} \mathrm{C}$, the iron + cohenite pair seemed to be much more abundant than wüstite and especially graphite. On the other hand, all the reduced Fe species were clearly progressively removed starting at temperatures between $500-600{ }^{\circ} \mathrm{C}$.

The major observations of non-ferrous products are:

- Graphite was especially prominent between $600-800{ }^{\circ} \mathrm{C}$ in the prograde phase of the experiment.

- Clinopyroxene appeared to be most abundant at $\sim 700^{\circ} \mathrm{C}$.

- Muscovite mica developed from $\sim 680^{\circ} \mathrm{C}$ and was relatively abundant at $800{ }^{\circ} \mathrm{C}$.

- Cristobalite was important in the $500-600{ }^{\circ} \mathrm{C}$ range. Although still present at higher temperatures, typical tetragonal cristobalite may have been preceded by either $C 222_{1}$-structured $\mathrm{SiO}_{2}$ or a hexagonal polytype of tridymite.

In addition, two new observations for the USCB material were made:

- $\quad$ Bayerite may have be an important admixing product that started to nucleate at $\sim 1100{ }^{\circ} \mathrm{C}$ and continued growing through both prograde heating and retrograde cooling.

- Graphite reflection at 2.03 A coincided with possible additional metallic iron.

The siderite heating experiment showed in detail how differences in the compositions of the initial starting materials, even in components present in negligible amounts, lead to different end results on combustion. These initial differences influence disintegration temperatures and are reflected in the mineral varieties that grow afterwards. Thus, as a naturally occurring, impure flux, siderite will certainly influence the products of combustion processes in coal-bearing rocks, but in ways that are difficult to predict.

Author Contributions: Conceptualization, J.C. and Ł.K.; methodology, Ł.K.; software, Ł.K.; validation, Ł.K.; formal analysis, Ł.K.; investigation, Ł.K, J.C.; resources, J.C.; data curation, Ł.K.; graphics: Ł.K.; writing-original draft preparation, Ł.K., J.C.; writing-review and editing, J.C., Ł.K.; supervision, J.C.; project administration, J.C.; funding acquisition, J.C. All authors have read and agreed to the published version of the manuscript.

Funding: This research was funded by NCN grants No. 2011/01/B/ST10/07588 and 2016/21/B/ST10/02293. 
Acknowledgments: Pádhraig Kennan (University College, Dublin, Ireland) is thanked for discussion and language correction. This manuscript has benefitted from the reviews by three Minerals anonymous reviewers.

Conflicts of Interest: The authors declare no conflict of interest.

\section{References}

1. Heffern, E.L.; Coates, D.A. Geologic history of natural coal-bed fires, Powder River basin, USA. Int. J. Coal Geol. 2004, 59, 25-47. [CrossRef]

2. Klika, Z.; Kozubek, T.; Martinec, P.; Kliková, C.; Dostál, Z. Mathematical modeling of bituminous coal seams burning contemporaneously with the formation of a variegated beds body. Int. J. Coal Geol. 2004, 59, 137-151. [CrossRef]

3. Rădan, S.-C.; Rădan, S. Paleo-Coal Fires in the Western Dacic Basin, Romania. In Coal and Peat Fires: A Global Perspective; Stracher, G.B., Prakash, A., Sokol, E.V., Eds.; Elsevier: Amsterdam, The Netherlands, 2013; pp. 339-349.

4. Gürdal, G.; Hoşgörmez, H.; Özcan, D.; Li, X.; Liu, H.; Song, W. The pproperties of Çan Basin coals (Çanakkale-Turkey): Spontaneous combustion and combustion by-products. Int. J. Coal Geol. 2015, 138, 1-15. [CrossRef]

5. Pone, J.D.N.; Hein, K.A.A.; Stracher, G.B.; Annegarn, H.J.; Finkleman, R.B.; Blake, D.R.; McCornack, J.K.; Schroeder, P. The spontaneous combustion of coal and its by-products in the Witbank and Sasolburg coalfields of South Africa. Int. J. Coal Geol. 2007, 72, 124-140. [CrossRef]

6. Muszyński, M.; Skowroński, A.; Lipiarski, I. Red beds of the collapse-type breccia from the "Marcel" Coal Mine (Upper Silesian Coal Basin, Poland). Geologia 2006, 32, 345-367, (In Polish with English Abstract).

7. Brooks, K.; Svanas, N.; Glasser, D. Evaluating the risk of spontaneous combustion in coal stockpiles. Fuel 1988, 67, 651-656. [CrossRef]

8. Stracher, G.B.; Prakash, A.; Sokol, E.V. Coal and Peat Fires: A Global Perspective, 1st ed.; Elsevier: Amsterdam, The Netherlands, 2011; 357p.

9. Stracher, G.B.; Prakash, A.; Sokol, E.V. Coal and Peat Fires: A Global Perspective, 2nd ed.; Elsevier: Amsterdam, The Netherlands, 2013; 554p.

10. Stracher, G.B.; Prakash, A.; Sokol, E.V. Coal and Peat Fires: A Global Perspective, 3rd ed.; Elsevier: Amsterdam, The Netherlands, 2015; 786p.

11. Stracher, G.B.; Prakash, A.; Sokol, E.V. Coal and Peat Fires: A Global Perspective, 5th ed.; Elsevier: Amsterdam, The Netherlands, 2019; 506p.

12. Gorova, A.; Pavlychenko, A.; Kulyna, S. Environmental aspects of waste management on coal mining enterprises. In New Developments in Mining Engineering 2015, Theoretical and Practical Solutions of Mineral Resources Mining; CRC Press: Boca Raton, FL, USA, 2015; 600p.

13. Nadłonek, W.; Cabała, J. Potentially toxic elements in soils and plants on a reclaimed coal-waste dump in southern Poland (preliminary study). Acta Geodyn. Geomater. 2016, 13, 271-279. [CrossRef]

14. Fabiańska, M.J.; Ciesielczuk, J.; Kruszewski, Ł.; Misz-Kennan, M.; Blake, D.R.; Stracher, G.; Moszumańska, I. Gaseous compounds and efflorescences generated in self-heating coal-waste dumps-a case study from the Upper- and Lower Silesian Coal Basins (Poland). Int. J. Coal Geol. 2013, 116-117, 247-261. [CrossRef]

15. Křibek, B.; Sýkorová, I.; Veselovský, F.; Laufek, F.; Malec, J.; Knésl, I.; Majer, V. Trace element geochemistry of self-burning and weathering of a mineralized coal waste dump: The Novátor mine, Czech Republic. Int. J. Coal Geol. 2017, 173, 158-175. [CrossRef]

16. Fabiańska, M.J.; Ciesielczuk, J.; Nádudvari, Á.; Misz-Kennan, M.; Kowalski, A.; Kruszewski, Ł. Environmental influence of gaseous emissions from self-heating coal waste dumps in Silesia, Poland. Environ. Geochem. Health 2019, 41, 575-601. [CrossRef]

17. Kruszewski, Ł.; Fabiańska, M.; Ciesielczuk, J.; Segit, T.; Orłowski, R.; Motyliński, R.; Kusy, D.; Moszumańska, I. First multi-tool exploration of a gas-condensate-pyrolysate system from the environment of burning coal mine heaps: An in situ FTIR and laboratory GC and PXRD study based on Upper Silesian materials. Sci. Total Environ. 2018, 640-641, 1044-1071. [CrossRef] [PubMed]

18. Ribeiro, J.; Da Silva, E.F.; Flores, D. Burning of coal waste piles from Douro Coalfield (Portugal): Petrological, geochemical and mineralogical characterization. Int. J. Coal Geol. 2010, 81, 359-372. [CrossRef] 
19. Ciesielczuk, J.; Kruszewski, Ł.; Majka, M. Comparative mineralogical study of thermally-altered coal-dump waste, natural rocks and the products of laboratory heating experiments. Int. J. Coal Geol. 2015, 139, $114-141$. [CrossRef]

20. Mendenhall, W.C. Shorter Contributions to General Geology; USGS Professional Paper; USGS: Washington, DC, USA, 1931.

21. Bean, J.H. The Iron Ore Deposits of Ulu Rompin, Malaya. Ph.D. Thesis, Durham University, Durham, UK, 1975; 382p. Available online: http://etheses.dur.ac.uk/8144 (accessed on 23 February 2020).

22. Zotov, A.; Mukhamet-Galeev, A.; Schott, J. An experimental study of kaolinite and dickite relative stability at 150-300 ${ }^{\circ} \mathrm{C}$ and the thermodynamic properties of dickite. Am. Min. 1998, 83, 516-524. [CrossRef]

23. Uchida, E.; Iiyama, J.T. On Kamaishilite, $\mathrm{Ca}_{2} \mathrm{Al}_{2} \mathrm{SiO}_{6}(\mathrm{OH})_{2}$, a New Mineral Dimorphous (Tetragonal) with Bicchulite from the Kamaishi Mine, Japan. Proc. Japan Acad. 1981, S7B, 239-243. [CrossRef]

24. Kruszewski, Ł.; Gatel, P.; Thiéry, V.; Moszumańska, I.; Kusy, D. Crystallochemical Behavior of Slag Minerals and the Occurrence of Potentially New Mineral Species from Lapanouse-de-Sévérac, France (Slag and Potentially New Minerals from Lapanouse-de-Sévérac, France). In Coal and Peat Fires: A Global Perspective; Stracher, G.B., Ed.; Elsevier: Amsterdam, The Netherlands, 2019; pp. 243-300.

25. Dick, H.J.B.; Erzinger, J.; Stokking, L.B. Shipboard Scientific Party, 1992. Site 504. In Proceedings of the Ocean Drilling Program: Initial Report; Ocean Drilling Program: College Station, TX, USA, 1992; Volume 140, pp. 37-200.

26. Watanabe, T.; Kasami, H.; Ohshima, S. Compressional and shear wave velocities of serpentinized peridotites up to $200 \mathrm{MPa}$. Earth Planets Space 2007, 59, 233-244. [CrossRef]

27. Potel, S.; Schmidt, S.T.; De Capitani, C. Composition of pumpellyite, epidote, and chlorite from New Caledonia-How important are metamorphic grade and whole-rock composition? Swiss J. Geos. Suppl. 2002, 82, 229-252.

28. Pasero, M.; Reinecke, T. Crystal chemistry, HRTEM analysis, and polytypic behavior of ardennite. Eur. J. Mineral. 1991, 3, 819-830. [CrossRef]

29. Orlandi, P.; Biagioni, C.; Pasero, M.; Mellini, M. Lavoisierite, $\mathrm{Mn}^{2+}{ }_{8}\left[\mathrm{Al}_{10}\left(\mathrm{Mn}^{3+} \mathrm{Mg}\right)\right]\left[\mathrm{Si}_{11} \mathrm{P}\right] \mathrm{O}_{44}(\mathrm{OH})_{2}$, a new mineral from Piedmont, Italy. Phys. Chem. Minerals 2013, 40, 239-249. [CrossRef]

30. Jóźwiak, W.K.; Kaczmarek, E.; Maniecki, T.P.; Ignaczak, W.; Maniukiewicz, W. Reduction behavior of iron oxides in hydrogen and carbon monoxide atmospheres. Appl. Catal. A Gen. 2007, 326, 17-27. [CrossRef]

31. Sokol, E.V.; Maksimova, N.V.; Nigmatulina, E.N.; Sharygin, V.V.; Kalugin, V.M. Combustion Metamorphism; Publishing House of the SB RAS: Novosibirsk, Russia, 2005; 312p, (In Russian, with some English Abstracts).

32. Kruszewski, Ł.; Ciesielczuk, J.; Misz-Kennan, M.; Fabiańska, M. Chemical composition of glasses and associationg mineral species in various pyrometamorphic rocks from coal-mining dumps of the Lower Silesia. Min. Spec. Pap. 2014, 42, 70-71.

33. Kruszewski, Ł.; Ciesielczuk, J.; Misz-Kennan, M. What have meteorites to do with coal fires? A case of Upper and Lower Silesian Basins. Min. Spec. Pap. 2012, 40, 28-29.

34. Sharygin, V.V. Metal-phospide-sulphide assosiation in paralavas from dump of the Korkino open pit, Chelyabinsk coal basin. In Proceedings of the Mineralogy of the Urals, Miass, Russia, 22-26 August 2011; pp. 186-192. (In Russian)

35. Vapnik, Y.; Galuskina, I.; Murashko, M.; Britvin, S.; Galuskin, E. The Hatrurim Complex-The New Unique Locality on World Mineral Map: The Review of Mineral Discoveries. In Proceedings of the Israel Geological Society, Annual Meeting, En Boqeq, Israel, 25-27 February 2014; pp. 143-144.

36. Britvin, S.N.; Vapnik, Y.; Polekhovsky, Y.S.; Krivovichev, S.V.; Krzhizhanovskaya, M.G.; Gorelova, L.A.; Vereshchagin, O.S.; Shilovskikh, V.V.; Zaitsev, A.N. Murashkoite, FeP, a new terrestrial phosphide from pyrometamorphic rocks of the Hatrurim Formation, South Levant. Miner. Petrol. 2019, 113, 237-248. [CrossRef]

37. Britvin, S.N.; Murashko, M.N.; Vapnik, Y.; Polekhovsky, Y.S.; Krivovichev, S.V.; Vereshchagin, O.S.; Shilovskikh, V.V.; Krzhizhanovskaya, M.G. Negevite, the pyrite-type $\mathrm{NiP}_{2}$, a new terrestrial phosphide. Am. Mineral. 2020, 105, 422-427.

38. Kruszewski, Ł. Geochemical Behavior of Trace Elements in the Upper and Lower Silesian Basin Coal-Fire Gob Piles of Poland (Geochemical Behavior of Trace Elements in Silesian Coal-Fire Gob Piles). In Coal and Peat Fires: A Global Perspective; Stracher, G.B., Ed.; Elsevier: Amsterdam, The Netherlands, 2019; pp. 407-449. 
39. Belgacem, K.; Llewellyn, P.L.; Kais, N.; Trabelski Ayadi, M. Thermal behaviour study of the talc. OAM RC 2008, 2, 332-336.

40. Sokol, E.V.; Kokh, S.N.; Sharygin, V.V.; Danilovsky, V.A.; Seryotkin, Y.V.; Liferovich, R.; Deviatiiarova, A.S.; Nigmatulina, E.N.; Karmanov, N.S. Mineralogical diversity of $\mathrm{Ca}_{2} \mathrm{SiO}_{4}$-bearing combustion metamorphic rocks in the Hatrurim Basin: Implications for storage and partitioning of elements in oil shale clinkering. Minerals 2019, 9, 465. [CrossRef] article distributed under the terms and conditions of the Creative Commons Attribution (CC BY) license (http://creativecommons.org/licenses/by/4.0/). 